KYIV-MOHYLA

HUMANITIES JOURNAL

KYIV-MOHYLA SCHOLARLY PEER-REVIEWED JOURNALS

Chornobyl as an Open Air Museum:

A Polysemic Exploration of Power and Inner Self

Author(s): Olga Bertelsen

Source: Kyiv-Mohyla Humanities Journal 5 (2018): 1-36

Published by: National University of Kyiv-Mohyla Academy

http://kmhj.ukma.edu.ua/ 


\title{
Chornobyl as an Open Air Museum: A Polysemic Exploration of Power and Inner Self ${ }^{1}$
}

\author{
Olga Bertelsen \\ European University Institute (Florence, Italy), \\ Robert Schuman Centre for Advanced Studies
}

\begin{abstract}
This study focuses on nuclear tourism, which flourished a decade ago in the Exclusion Zone, a regimented area around the Chornobyl Nuclear Power Plant(Ukraine) established in 1986, where the largest recorded nuclear explosion in human history occurred. The mass pilgrimage movement transformed the place into an open air museum, a space that preserves the remnants of Soviet culture, revealing human tragedies of displacement and deaths, and the nature of state nuclear power. This study examines the impact of the site on its visitors and the motivations for their persistence and activities in the Zone, and argues that through photography, cartography, exploration, and discovery, the pilgrims attempt to decode the historical and ideological meaning of Chornobyl and its significance for future generations. Ultimately, the aesthetic and political space of the Zone helps them establish a conceptual and mnemonic connection between the Soviet past and Ukraine's present and future. Their practices, in turn, help maintain the Zone's spatial and epistemological continuity. Importantly, Chornobyl seems to be polysemic in nature, inviting interpretations and shaping people's national and intellectual identities.
\end{abstract}

Key Words: Chornobyl, open air museum, polysemy, pilgrimage, identity.

\section{iv}

An open air museum involves the resurrection of old buildings and the re-creation of past landscapes and cultures for educational purposes. The idea was born in Scandinavia, in Oslo in the early 188os, through Oscar II's simple collection of old farm buildings. The concept spread to Norway and Sweden as an attempt to preserve a vanishing agrarian way of life before industrialization and urbanization would sweep its remnants into oblivion. ${ }^{2}$ Over approximately 15 o years, open air museums developed rapidly and today exist on every continent except South America in a rich variety of forms. One of the objectives of such museums is to bring the past closer to their visitors, inviting them to experience it and to compare it with the present.

1 I would like to thank Serhii Plokhy, Dale A. Bertelsen, and anonymous reviewers for their thoughtful comments at earlier stages of this research.

2 Sten Rentzhog, Open Air Museums: The History and Future of a Visionary Idea (Stockholm:

Carlssons; Ostersund: Jamtli, 2007), $15^{2}$. 
From its inception the movement of creating these types of cultural institutions has been criticized for the absence of authenticity and accuracy in recreating the past. Such museums, the critics argue, will always remain a simulation of life in another time, and simulations often drastically differ from the realities of the past. Yet there is a more optimistic view, according to which open air museums function as powerful time machines that intellectually and emotionally transport people into the past, enabling them to engage in an experiential interpretation of history and in unique learning experiences. ${ }^{3}$ The Swedish art historian Sten Rentzhog has posited that these cultural institutions serve as bridges between generations, sanctioning historical and cultural continuity. ${ }^{4}$

There are also other sorts of open air museums that are more authentic than those that simulate a period in history, although they can only be identified as museums with caution and reservations. Some emerge spontaneously, from custom and practice, rather than from a conscious effort and desire to create them. For example, abandoned sites of nuclear disasters, such as Chornobyl, emerged as open air museums that have become monuments to human recklessness, neglect, and violence, and reminders about the dangers of technological innovations. Altered and modified by time and human activities, these dead zones nevertheless present unique opportunities to observe and experience the past. They are not cultural institutions, although some practices within them were institutionalized and regimented. These sites were abandoned, not re-created, and this major difference prompts us to refer to them as museums only conditionally, in a metaphorical sense.

What makes these sites museums is their visitors. Traditional open air museums attract audiences through advertisements and the activities of their organizers. The sites of nuclear disasters are typically silent, although their aesthetic and political (representational) space speaks to us in many voices. The paths toward them are investigated, discovered, and carefully chosen because they are not always legal. But what definitely unites conventional open air museums and spontaneous ones, such as Chornobyl, is their ability to facilitate intimate discoveries, including self-identification and people's role and place in history. Through the eyes of an intellectual, an artist, a writer, or a photographer, the historical artifacts and material culture of open air museums are transformed into art, and Chornobyl has been no exception. ${ }^{5}$ They speak to us, as any art does, enabling us to remember, learn, and discover.

The American scholar Jeffrey K. Smith has argued that in the process of looking at a work of art in a museum, people somehow bring themselves into the picture, personalizing their experiences and associatively reflecting on something that once

3 Jay Anderson, Time Machines: The World of Living History (Nashville, TN: American Association for State and Local History, 1984).

4 Rentzhog, Open Air Museums, 409.

5 See, for instance, "The Chernobyl VR Project" that allows us to virtually and vividly observe the Chornobyl site at The Farm 51, July 1, 2016, accessed August 17, 2018, http://www.thefarm51.com/projekt/chernobyl-vr-project/. 
happened in their lives. The museum walls and their art talk with us and we react by returning to our past, which is often forgotten and otherwise irretrievable. ${ }^{6}$ Art stimulates and rejuvenates memories (or our perceptions) of the past, which are a museum in their own right - a "museum of abandoned (or forgotten) secrets," as Oksana Zabuzhko has defined them. ${ }^{7}$ What one sees in a work of art can tell us a great deal about a person. The "art as mirror" concept is ancient and serves as a perfect model for explaining people's dispositions, beliefs, and values, as well as the role and functions of museums, libraries, and other cultural institutions. ${ }^{8}$ They offer us myriad opportunities: they function as time machines, transporting us to our past; ${ }^{9}$ they help us better understand ourselves; or on the contrary, they might confuse us more as distorted carnival mirrors, presenting images of the past uglier or funnier than they were in reality.

The distinction, however, between conventional and spontaneous open air museums is much more serious and profound than it might seem at first glance. Historically and philosophically, organized exhibitions and museums function as spectacle and surveillance places, as cultural sociologist Tony Bennett has posited. ${ }^{10}$ The aesthetics and beauty of big open spaces are mesmerizing and undeniable, but they are also the spaces where visitors can see everything and be seen by everyone, and this disciplinary factor, combining with the visionary effect, contributed to Bennett's concept of the "exhibitionary complex," which alludes to the model of the Panopticon created by Jeremy Bentham and explained by Michel Foucault." The reasonable privacy of spontaneous open air museums excludes outright surveillance, and their visitors have extreme freedom in intimately experiencing and observing places and their landscapes, breathing new life into their material culture, and assigning new meanings to objects located within their space.

Their privacy of course is relative, especially lately, when the commercialization of nuclear sites and nuclear tourism has become commonplace, and more and more people attempt to penetrate the zone of tragedy and technological failure, illegally crossing the borders between the "normal" and "morbid" worlds, established by the authorities. Having penetrated the zone, one deals largely with the frozen and lifeless space of time and destruction, which minimizes regimentation and the effect of "panopticism," associated with self-monitoring and self-regulation. ${ }^{12}$ In spontaneous

6 Jeffrey K. Smith, The Museum Effect: How Museums, Libraries, and Cultural Institutions Educate and Civilize Society (New York: Rowman \& Littlefield Publishers, 2014), 87.

7 Oksana Zabuzhko, Muzei pokynutykh sekretiv [A Museum of Abandoned Secrets] (Kyiv: Spadshchyna, 2012).

8 Smith, The Museum Effect, 87-89.

9 For an elaboration of this metaphor, see Anderson, Time Machines.

10 Tony Bennett, The Birth of the Museum: History, Theory, Politics (London: Routledge, 1995), 59-88.

11 Michel Foucault, Discipline and Punish: The Birth of the Prison, trans. A. Sheridan (New York: Vintage Books, 1995), 195-228.

12 Beyond Bennett, for a thought-provoking discussion about the effects of exhibitions and panopticism, see Simon Gunn, History and Cultural Theory (London: Pearson Education 
open air museums, such as Chornobyl, external and internal control is replaced by selfobservation and contemplation. Importantly, unlike conventional open air museums, nuclear sites tell a story of destruction, not progress. For many Ukrainian nuclear tourists and "stalkers,"13 Chornobyl also tells the story of Soviet imperial subversion, rejuvenating their national consciousness and contributing to their new national identities. Tranquilized by time, the secrets of the past beckon them, inviting them to commit to routine and frequent pilgrimages to the Chornobyl Zone. Their trips have transformed the Zone into an open air museum that persistently induces a polysemic exploration of institutional power and inner self.

A close focus on this truly mass pilgrimage that has made many young Ukrainians conscious of their past will help illustrate this point. Among the Zone's visitors are young Ukrainian students, scholars, writers, and artists, people who have written a spatial history of Chornobyl, who have challenged the official narrative of the tragedy, and have created its "emotional cartography." 14 They sought their childhood memories and the secrets of the past at the site of the nuclear disaster, simultaneously discovering something new for themselves - their new self-identifications and freedom.

The sections that follow provide the historical context of the emergence of Chornobyl as a spontaneous open air museum, offer a discussion of the reasons behind the Ukrainian pilgrimage to the Zone that surrounds the Chornobyl Nuclear Power Plant (AES), and examine the role and the meaning of Chornobyl for a young generation of Ukrainians who became frequent visitors there over the last decade.

Limited, 2006), 94-96.

13 Initially, the notion of a "stalker" emerged in Arkady and Boris Strugatsky's science fiction novel Piknik na obochine (Roadside Picnic), published in Moscow's journal Avrora in 1972 (the novel was translated into English by Antonina W. Bouis and was published in 1977 by the MacMillan Publishing Co., Inc., New York). The Strugatsky brothers borrowed this term from Rudyard Kipling's novel Stalky \& Co., a narrative about British school boys, adolescents whose "have been there" and "done it all" attitudes encouraged them to adopt cynical views about authority and patriotism. Despite the somewhat violent and hooligan nature of the main character Stalky, he also exhibited noble and kind features. This notion gained a new meaning in Andrei Tarkovsky's film Stalker (1979). Stalker was a slightly mad individual, obsessed with his quest for truth and happiness who led groups of people to the "dead" Zone that was allegedly capable of healing people's wounds and making them happy. Altruistic and kind by nature, Stalker helped other unhappy people like him reach the Zone's "magic" room, where miracles had happened. Individuals who lead nuclear tourists to the Chornobyl Zone defined themselves as stalkers.

14 Kirill Stepanets, Denis Vishnevskii, and Sergei Paskevich, Chernobylskaia zona glazami stalkera [The Chornobyl Zone Through the Eyes of a Stalker] (Kyiv: Sky Horse Publishing House, 2017); Chad Gracia, The Russian Woodpecker (documentary film; 2015); Markiian Kamysh, Oformliandiia abo prohulianka v zonu [A Formative Land, or A Walk to the Zone] (Kyiv: NoraDruk, 2015); see also Valerii Puzik's interview with Markiian Kamysh in Litaktsent, January 5, 2016, accessed August 18, 2018, http://litcentr.in.ua/blog/2016-01-05-78. 


\section{Contextualizing the Disaster and Post-Disaster Realities}

In the mid-sixties, inspired by the success of the Russian Federation in employing nuclear energy for its economic development, the first deputy head of the Ukrainian government and an enthusiastic supporter of this alternative source of energy, Oleksandr Shcherban, advocated the construction of new electric-power-generating facilities in Ukraine. In 1966 the search for a site that would suit the needs of the reactor was completed. The construction of the AES began in 1970 near the village of Kopachi, approximately 140 kilometers from Kyiv. ${ }^{15}$ In early December 1971, the highest party leadership in Moscow expressed their concerns about the slow tempo of construction and pressed the Politburo of Ukraine to intensify the process. Nuclear energy should have been tamed and utilized immediately, following the plans of rapid socialist construction envisioned by the center. The First Secretary of the Central Committee of the Communist Party of Ukraine (TsK KPU), Petro Shelest, called for an urgent meeting of the TsK KPU and the Council of Ministers of the UkrSSR (Rada Ministriv, RM hereafter) where the Chornobyl matter was to be discussed. Prominent Ukrainian writers were also invited to this meeting: Yurii Smolych headed the delegation that represented the Ukrainian Union of Writers. One intellectual sarcastically noted that those in Moscow accused Ukraine of dragging its feet, acting as if Ukraine was building a grocery store. The meeting produced a top secret resolution, signed by Shelest and the head of the RM, Volodymyr Shcherbytskyi, which ordered "Kremenchukgesbud" to complete the construction of the AES as soon as possible. The Ministry of Energy of the USSR supervised the project. ${ }^{16}$

Yet Shcherbytskyi's correspondence from late April to early June 1975 with Aleksei Kosygin, head of the Council of Ministers of the USSR and a member of the TsK KPSS, reveals that various Soviet factories failed to live up to their promises, and delivered no parts for the Zaporizhzhia and Chornobyl AESs on time. Shcherbytskyi requested assistance from Kosygin, who dumped this issue on the shoulders of his deputy, Veniamin Dymshyts. Dymshyts pressed all parties involved and, as a result, the Ukrainian party leadership promised him that the Chornobyl AES would be completed by August 27, 1975. $\cdot^{17}$ The first two units were completed in 1977. Units 3 and 4 were launched in $1983 .{ }^{18}$ By 1983 four power units worked at full capacity, and the AES was staffed by residents of Prypiat, a town two kilometers north-west of Chornobyl. ${ }^{19}$

\footnotetext{
15 Serhii Plokhy, Chernobyl: The History of a Nuclear Catastrophe (New York: Basic Books, 2018), 31.

16 TsDAHOU $1 / 10 / 939 / 53-57$.

17 TsDAHOU $1 / 25 / 1259 / 1-4$.

18 V. Bar'yakhtar, V. Poyarkov, V. Kholosha, and N. Shteinberg, "The Accident: Chronology, Causes, and Releases," in The Chornobyl Accident: A Comprehensive Risk Assessment by Victor Poyarkov et al., ed. George J. Vargo (Columbus \& Richland, OH: Battelle Press, 200o), 5.

19 Iurii Shcherbak, Chernobyl: A Documentary Story, trans. Ian Press (New York: St. Martin's Press, 1989), 12. Shcherbak's Chernobyl was published in Russian in the Soviet journal Yunost (in two
} 
The explosion occurred in Unit 4 of the AES after midnight on April 25-26, 1986 during the night shift, which supervised a series of experiments. The goal of these tests was to identify whether "the plant would respond to a turbine/generator trip concurrent with a loss of offsite power." ${ }^{20}$ The chronology of the tragedy and the reasons for it have been analyzed in hundreds of publications. Beyond the nuclear explosions, a prolonged fire contributed greatly to the level of destruction and the scale of the environmental disaster. The graphite moderator in the reactor core in Unit 4 caught on fire, and the graphite fire was finally extinguished on May 9, 1986, releasing into the atmosphere $4 \%$ of the nuclear material. ${ }^{21}$ Immediately after the explosions, through fallout, radioactive iodine-131 found its way into water supplies and food. ${ }^{22}$ The highest level of cesium soil contamination was registered in Belarus, Russia, and Ukraine. As a result, between the eighth and eleventh day after the explosion approximately 90,0oo people were evacuated from 170 towns, settlements, and villages. Within the next few weeks the total number of people who moved out of the area within a 3o-kilometer radius around the AES (the "Exclusion Zone") reached 135,00o.23

Belarus suffered and continues to suffer the most because of its geographic specificity and the initial Western direction of the wind and precipitation. The highest radionuclide transport rates occur in areas with high moisture content. Belarus is famous for its forests and swamps, a factor that, among others, increased the vertical cesium distributions. ${ }^{24}$ Not surprisingly, the radionuclides contaminated $26 \%$ of Belarusian territories, $4.8 \%$ of Ukrainian lands, and $0.5 \%$ of Russian territories. Chornobyl forced

issues in the summer of 1987) and also in Ukrainian in the Ukrainian journal Vitchyzna (in the spring of 1988).

$20 \quad$ Bar'yakhtar et al., "The Accident: Chronology, Causes, and Releases," 9.

21 Bar'yakhtar et al., "The Accident: Chronology, Causes, and Releases," 14.

22 According to several studies, people's (especially children's and adolescents') exposure to small doses of I-131 is the major cause of thyroid cancer which develops due to residual tissue radiation damage caused by the radioisotope. Typically, people develop this type of cancer years after exposure, long after iodine-131 decays. See Steven L. Simon, André Bouville, and Charles E. Land, "Fallout from Nuclear Weapons Tests and Cancer Risks," American Scientist 94 (2006): 48-57; "Fallout Studies: Recent and Current Studies of Radioactive Fallout," National Cancer Institute, 2017, accessed November 6, 2017, https://dceg.cancer.gov/research/what-westudy/fallout-studies.

23 Zhores Medvedev, The Legacy of Chernobyl (New York; London: W. W. Norton \& Company, 1992), 151. On the evacuation issue and numbers of displaced people, see also David R. Marples, Chernobyl and Nuclear Power in the USSR (New York: St. Martin's Press, 1986), 141-46; and V. Poyarkov, "Introduction," in The Chornobyl Accident: A Comprehensive Risk Assessment by Victor Poyarkov et al., ed. George J. Vargo (Columbus \& Richland, OH: Battelle Press, 200o), 3. V. Shestopalov and V. Poyarkov, "Environmental Contamination," in The Chornobyl Accident: A Comprehensive Risk Assessment by Victor Poyarkov et al., ed. George J. Vargo (Columbus \& Richland, OH: Battelle Press, 200o), 168. 
the evacuation of 485 Belarusian villages and towns, and every fifth Belarusian today lives on contaminated territory. ${ }^{25}$

Two hundred ten military units and approximately 340,000 people worked in the Zone near the reactor to remediate the consequences of the Chornobyl accident. ${ }^{26}$ Approximately 117,000 workers built the "Shelter" (the sarcophagus) to prevent the radionuclides from spreading. ${ }^{27}$ The construction of the shelter came at an enormous price: the collective dose of radiation received by the workers was tremendous, and the shelter's structural limitations were substantial. ${ }^{28}$ The remote-control equipment used on the site lacked precision, which resulted in gaps between the metal parts of the shelter. In other words, the sarcophagus has never been airtight, and the reactor continued to spew deadly radionuclides into the atmosphere. The liquidators dug out 800 mounds and trenches within the Exclusion Zone where they buried contaminated animals, houses, equipment, trees, and soil..9 According to the official data, three people died on April 26, and twenty-eight more died from the effects of deadly radiation shortly after the explosion.

The Academy of Sciences in Moscow was ordered to urgently design a long-term plan for the decontamination of the AES and its adjacent territories. Today we have a number of explanations about the flaws of this plan but what is important is that the urgency of the situation and the plan of action were translated into several years of controversial tactics that negatively affected the lives of thousands, if not millions, of people in Belarus, Ukraine, Russia, and many European countries. During the first two years after the explosion, two-thirds of the decisions concerning Chornobyl were made by the Politburo in Moscow. Later on, its activities noticeably decreased. The Politburo's control became extremely weak, and the task of social support for the Chornobyl community and of creating a comprehensive environmental program became a burden for many local Ukrainian officials. ${ }^{30}$ The Ministry of Energy of the USSR collected and processed information about radioactive contamination of the territories and the isotopic content of soil and water, but did little to use this information for alleviating

25 Svetlana Alexievich, Chernobylskaia molitva: Khronika budushchego [Chernobyl Prayer:

A Chronicle of the Future] (Moscow: Vremia, 2016), 6-7.

26 I. Los' and V. Poyarkov, "Individuals: Accident Remediation Personnel and Public Doses," in

The Chornobyl Accident: A Comprehensive Risk Assessment by Victor Poyarkov et al., ed. George J. Vargo (Columbus \& Richland, OH: Battelle Press, 2000), 181.

27 Victor Poyarkov, "Introduction," in The Chornobyl Accident: A Comprehensive Risk Assessment by Victor Poyarkov et al., edited by George J. Vargo (Columbus \& Richland, OH: Battelle Press, 2000), 3. The construction of the Shelter began in May and was completed in November 1986. V. Bar'yakhtar, V. Poyarkov, V. Kholosha, and V. Kukhar', "The Shelter: Containing the Destroyed Reactor," in The Chornobyl Accident: A Comprehensive Risk Assessment by Victor Poyarkov et al., ed. George J. Vargo (Columbus \& Richland, OH: Battelle Press, 2000), 40. 
the consequences of the radiation or to help people who suffered from them; the statistics were top secret. ${ }^{31}$

More tragically, Moscow's promises to help Ukraine alleviate the consequences of the disaster remained unfulfilled. The 23rd Party Congress emphasized that the Soviet government and its all-union budget would assume all expenses for the people's relocation, the decontamination program, and medical assistance. ${ }^{32} \mathrm{~A}$ special account was created in the State Bank of the USSR, where funds were allotted specifically for the needs of the Chornobyl community and decontamination programs..$^{33}$ Interestingly enough, after the collapse of the USSR, Russia inherited these funds (including the party money, as well as many other assets) that were officially the property of the Union and the three affected republics, not the RSFSR alone. ${ }^{34}$ There were numerous attempts by Ukrainian activists to trace the disappearance of these funds, but to no avail.

Activists also grew skeptical about the official version of the causes of the accident, formulated in the July 14, 1986 resolution of the TsK KPSS. According to the conclusions of the State Commission that created the foundation for this resolution, the explosion was the result of the incompetence and irresponsibility exhibited by the leadership of the Chornobyl AES. ${ }^{35}$ Moscow also blamed the regional Ministries for not paying attention to their cadre policies and their unsatisfactory work in implementing party tasks to ensure the nuclear power plant's safe work regime. ${ }^{36}$

Assessments by leading Ukrainian scientists specializing in nuclear power plants differed somewhat from the official version. They added another dimension to the causes of the tragedy, arguing that the design flaws in the reactor control and protection system (RCPS) were known before the tragedy, and those who operated the reactor

$31 \quad$ Liubov Kovalevskaia, Chernobyl. "DSP." Posledstviia Chernobylia [Chornobyl. "DSP."

The Consequences of Chornobyl] (Kyiv: Abris, 1995). Also available at Chernobyl. Pripiat:

Obo vsiom ponemnogu, February 7, 2012, accessed August 17, 2018, http://pripyat-city.ru/

books/178-chernobyl-dsp.html.

32 TsDAHOU $1 / 2 / 1065 / 128$.

33 TsDAHOU $1 / 11 / 1374 / 18$.

34 Similarly, the Union's assets in the form of properties abroad, residences of Soviet embassies and consulates, were appropriated by the Russian Federation after 1991 through manipulation and blackmail. See, for instance, the first Soviet and Russian Ambassador to Israel Aleksandr Bovin's account about the process of appropriation of the Soviet Consulate in Tel Aviv and preventing Ukraine from decisive steps in claiming the rights to the property. Aleksandr Bovin, 5 let sredi yevreev i midovtsev, ili Izrail iz okna rossïskogo posolstva (iz dnevika) [Five Years Among Jews and MID People, or Israel From a Window of the Russian Embassy (From the Diary)] (Moscow: Zakharov, 2000).

The State Commission was created on the second day after the accident. The deputy head of the Council of Ministers of the USSR Boris Shcherbina was appointed its chair. 
relied largely on their experience and intuition rather than on the instruments' objective data. ${ }^{37}$ In addition, they criticized the work on the shelter and its fundamental structural weakness. They suggested that unless serious urgent measures were undertaken that would prevent another nuclear disaster, its roof might eventually collapse, forming a radioactive dust cloud.

Some insisted that people's incompetence and the reactor's design flaws were exacerbated by general chaos and the absence of a single agency responsible for the decision-making process. The Soviet system in which everyone in the government and various institutions was responsible for everything produced a situation in which no one was responsible for anything. ${ }^{38}$ Mechanisms of accountability were never established: in fact, they were deliberately obscured by central and regional party leaders who, wishing to be in charge, delegated and dispersed their powers and responsibilities through a maze of bureaucratic channels and hierarchies. As Harvard professor Serhii Plokhy has posited, beyond the irresponsibility of station personnel who violated procedures and safety rules, the catastrophe's "roots lay in the interaction between major flaws in the Soviet political system and major flaws in the nuclear industry." 39

Many claim that the predictions of journalist Liubov Kovalevska, who before the explosion worked for the Prypiat newspaper Trybuna enerhetyka (The Energy Worker Tribune), were striking. She seemed to predict the accident by stressing in writing the enormous degree of incompetence and nepotism that had blossomed at the nuclear plant long before the tragedy. Because of special perks and privileges offered to the operators of the reactor, it was virtually impossible to be hired there unless those interested in a position had a sponsor. A system of acquaintances and dynasties was firmly in place which greatly affected the quality of people's performances. ${ }^{40}$

Since 1986, thousands of reports, accounts, and studies have been published about Chornobyl and about the heroism of the liquidators. In some major way, their authors reached a consensus pertaining to the causes of the accident and the colossal degree of damages caused by radiation. In 2005, in the translator's preface to Svetlana Alexievich's oral history of Chornobyl, Keith Gessen posited that "no one intentionally set it [Unit 4] off." ${ }^{41}$ This view was confirmed by the official conclusion offered by the State Commission on Chornobyl and was established as a fact which has been engraved in the historiography of Chornobyl.

37 Bar'yakhtar et al., "The Shelter," 74; Bar'yakhtar et al., "The Accident: Chronology, Causes, and Releases," 7-8; George J. Vargo, "Editor's Foreword," in The Chornobyl Accident: A Comprehensive Risk Assessment by Victor Poyarkov et al., ed. George J. Vargo (Columbus \& Richland, $\mathrm{OH}$ : Battelle Press, 2000), xi.

38 Bar'yakhtar et al., "The Accident: Chronology, Causes, and Releases," 16-17.

39 Plokhy, Chernobyl, 347.

40 Shcherbak, Chernobyl, 15-21.

41 Keith Gessen, "Translator's Preface," in Voices from Chernobyl: The Oral History of a Nuclear Disaster by Svetlana Alexievich, trans. Keith Gessen (New York: Picador, 2005), xi. 
Yet for some Ukrainians the scenario in which a poorly designed reactor was staffed with incompetent people provoked a new set of questions that suggested a more complex course of events that had preceded the explosion of Unit 4. The 2011 research by Ukrainian physicist and scientist Mykola Kravchuk constitutes one of the most controversial studies written over the last decade that has implicitly affirmed that the explosion was not actually an accident but a deliberate act with a specific agenda. Interestingly enough, Kravchuk could not find anyone interested in publishing his research in Ukraine, finally publishing it in Moscow. In his work he challenged the view of nuclear power expert Grigori Medvedev who, although stressing the experience and competence of the reactor's operators as crucial factors in preventing accidents, gravitated toward the version that explained the Chornobyl explosion through the reactor's fundamental design flaws and imperfections. ${ }^{42}$ Kravchuk's analysis of available information and sources has emphasized the human factor in the tragic events that unraveled during the night of April 25-26 and thereafter, and ultimately has suggested a close connection between the odd behavior of the operators of the AES and their supervisors in Moscow. ${ }^{43}$ In other words, Kravchuk has argued that the explosion might not have occurred without a very specific plan of action conceived at the highest level and later implemented. ${ }^{44}$ Curiously, the popular feeling that the disaster was an intentional plan implemented successfully on April 26, 1986 was formulated by many of those who worked at the AES immediately after the tragedy, but this idea remains unsubstantiated by any credible evidence. ${ }^{45}$

This scenario, however, has been recently reinforced by an independent investigation conducted by Fedir Oleksandrovych, a Kyivite artist and a nuclear tourist, whose frequent visits to the Chornobyl Zone provoked his interest in the logistics and reasons behind the tragedy. His research is built on circumstantial evidence, and it is certainly doubtful for many reasons that his argument might be advanced and supported by more solid evidence in the future. Nevertheless, people like Oleksandrovych ask

Grigori Medvedev, The Truth about Chernobyl, trans. Evelyn Rossiter (New York: Basic Books, Inc., 1991), 258-59. Medvedev's Chernobylskaia khronika was published in Russian in Moscow in 1989 .

Nikolai Kravchuk, Zagadka Chernobylskoi katastrofy (Opyt nezavisimogo issledovaniia) [The Mystery of the Chornobyl Catastrophe: Experience of Independent Research] (Moscow: "AIRO-XXI," 2011), 15.

44 For the specific points of Kravchuk's explanations, see Kravchuk, Zagadka, and Nikolai Kravchuk (interview with Anastasiia Kozlova), "Tragediia v Chernobyle byla umyshlena! [The Tragedy at Chornobyl Was Planned!]," Newsland, July 23, 2013, accessed August 17, 2018, https://newsland.com/community/88/content/tragediia-v-chernobyle-bylaumyshlena/2207091. Kravchuk seems to believe that the Politburo and the new leadership in the Kremlin, those who encouraged Gorbachev's perestroika, might have come up with the plan to blow up the AES to undermine the integrity of the USSR, a development that might eventually lead to its demise. 
legitimate questions about the roots of the tragedy, ultimately placing Chornobyl in the category of mysteries that "awaits decoding," a "mystery for the twenty-first century," as the Belorussian journalist and writer Alexievich has suggested. ${ }^{46}$ Many of those in Ukrainian society, who suffered in the past and continue to suffer today from psychological trauma and serious medical conditions caused by displacement, radiation, and social and psychological entrapment, continue to express doubts about the accidental nature of the disaster. Anastasiia Zanuda, for instance, has suggested that at the very least, one should speak of the "entirely predictable" nature of Chornobyl. ${ }^{47}$

Regardless of the nature and origin of these views, Alexievich's 2015 Nobel Prize Award in Literature and her work on Chornobyl, and American film director Chad Gracia's film The Russian Woodpecker reinvigorated popular and scholarly interest in the Chornobyl accident and its consequences. ${ }^{48}$ Importantly, the mass pilgrimage movement and new Ukrainian art and literature on nuclear tourism were provoked by Ukrainian youth's initial interest in the horror computer game S. T. A. L. K. E. R., a project of the Ukrainian video game company "GSC Game World" and its founder Sergei Grigorovich, who developed this game for Microsoft Windows. The real events in Chornobyl, photographic images of the Zone, and the Strugatsky brothers' ideas served as the foundation for this game and the reasons for the international success of the product. ${ }^{99}$ When young people had finally satiated their hunger and interest in the virtual game, they were desperate to see its blueprint — the real site of Chornobyl.

Thousands of young Ukrainians "populated" the Zone, contributing greatly to the formation of a phenomenon - a routine pilgrimage to the Zone, which for many grew into an obsession. Some used official tour guides; others chose illegal paths to penetrate the Zone, employing the stalkers' service. Stalkers (or "samokhody," or 'illegals," or "nuclear tourists") became a widespread term identifying those who illegally travel to the Zone and explore various sites there..$^{50}$ In contrast to other illegals who live off the Zone, stealing metal and other items abandoned in the 1980s, most stalkers pursue other than

\footnotetext{
46 Alexievich, Chernobylskaia molitva, 31.

47 Anastasiia Zanuda, "Chornobyl-3o: spohady, zasvidcheni arkhivamy KDB [Chornobyl-3o:

Memoirs Confirmed by the KGB Archives]," BBC Ukraina, April 25, 2016, accessed August

17, 2018, http://www.bbc.com/ukrainian/society/2016/o4/16o419_chornobyl_kgb_archives_ memories_az.

“The Nobel Prize in Literature 2015 (Svetlana Alexievich)," Nobelprize.org, 2015, accessed August 13, 2018, https://www.nobelprize.org/nobel_prizes/literature/laureates/2015/; Gracia's film was among the 2015 Sundance Film Festival award winners. See "2015 Sundance Film Festival Award Winners," Sundance, 2015, accessed November 6, 2017, https://www2.sundance.org/pdf/ festival-info/2015AwardWinners.pdf.

The sales of the game (the circulation was approximately 5 million copies) reached more than $\$ 100$ million; for a more detailed discussion about this computer game, see the interview of Grigorovich and the founder of the Sky Horse Publishing House Vladimir Nevzorov in Stepanets et al., Chernobylskaia zona, 370-9o.

Stepanets et al., Chernobylskaia zona, 29.
} 
commercial purposes. What unites them is their appreciation of the Zone's beauty and their gravitation towards creativity and self-expression. Many of them attempt to revisit the last days of the Soviet empire and its politics of silence. Remarkably, their efforts reveal the emergence of national consciousness among Ukrainian youth, inspired by anti-imperial and patriotic sentiments borne by state violence under Yanukovych, and Russia's aggression against Ukraine. Their research, publications, and creative art speak volumes for their new identities, contributing greatly to scholarship on Chornobyl and shaping their unique voices in art, literature, and politics.

Chornobyl is crucial to our understandings of the political trends of late Soviet socialism and its influence on Soviet Ukrainian society, ${ }^{51}$ but it is equally important to assess how Chornobyl continues to shape the intellectual and ideological worlds of the citizens of independent Ukraine. The stalker movement and its products help us realize exactly that. Similarly, contemporary Western art and films illuminate concerns, insecurity, and people's transformations associated with Chornobyl, which has never been a national but rather a global tragedy. The Polish artist Karolina Kowalczyk's striking ability to rejuvenate the traditions of a Slavic paper-cutting folk art that dates to the mid-19th century immerse us in the world of the Chornobyl tragedy, a very personal matter for Karolina that triggers her painful memories and experiences.52 Gracia's The Russian Woodpecker is another example of Western interest in post-Chornobyl realities and people's identities in Ukraine. This film, which featured Oleksandrovych's personal history, accentuated the evolution of a person's views, perceptions, and art under Chornobyl's influence. His story reverberated in the hearts of many around the world who experienced displacement, physical and psychological enclosure, and hardships associated with authoritarianism..$^{53}$ Undoubtedly, Chornobyl helped many young Ukrainians identify some parallels between Soviet Ukraine and independent Ukraine, where secrecy, silence, and the non-transparency of political behavior played and continue to play a crucial role in people's lives.

For many of them, the Exclusion Zone remains a magnet and a place to which they return in search of their past, their identity, and their freedom. Illegal tourism to the Chornobyl AES has blossomed since 1986, but those who travel to Chornobyl plundering people's abandoned houses and ravaging industrial remnants of rusted machinery in search of spare parts and precious metals are deliberately left out of the

$5^{1} \quad$ On this topic, see Catherine Wanner, Burden of Dreams: History and Identity in Post-Soviet Ukraine (University Park: Pennsylvania State University Press, 1998), 27-33.

Chloe Riley, "For Polish Artist, Chernobyl Nuclear Disaster Hits Close to Home," Chicago

Tonight, April 18, 2016, accessed August 13, 2018, https://chicagotonight.wttw.com/2016/o4/18/ polish-artist-chernobyl-nuclear-disaster-hits-close-home; see also Karolina Kowalczyk's art at her official site, accessed August 13, 2018, http://www.karolinaart.com/karolina-art. 
picture. Their motives are transparent and less interesting than those of people who have transformed post-accident Chornobyl into an open air museum.

\section{The Aesthetics and "Emotional Cartography" of the Zone}

Chornobyl and Prypiat have become an attraction for many reasons and for many people, including non-Ukrainians. Today nuclear tourism is quite popular, and one can pay a fee to be brought to the Zone to observe the remnants of Prypiat and the Chornobyl AES. For instance, Andrew Leatherbarrow from Great Britain went on a trip to Chornobyl in late 2011, the 25th anniversary of the explosion, took hundreds of photographs and wrote a book about Chornobyl and his experiences in the Zone. ${ }^{54}$ Many foreign tourists perceive the Zone as Terra Incognita, a place that has been romanticized, heroized and mythicized. Importantly, scholars create international

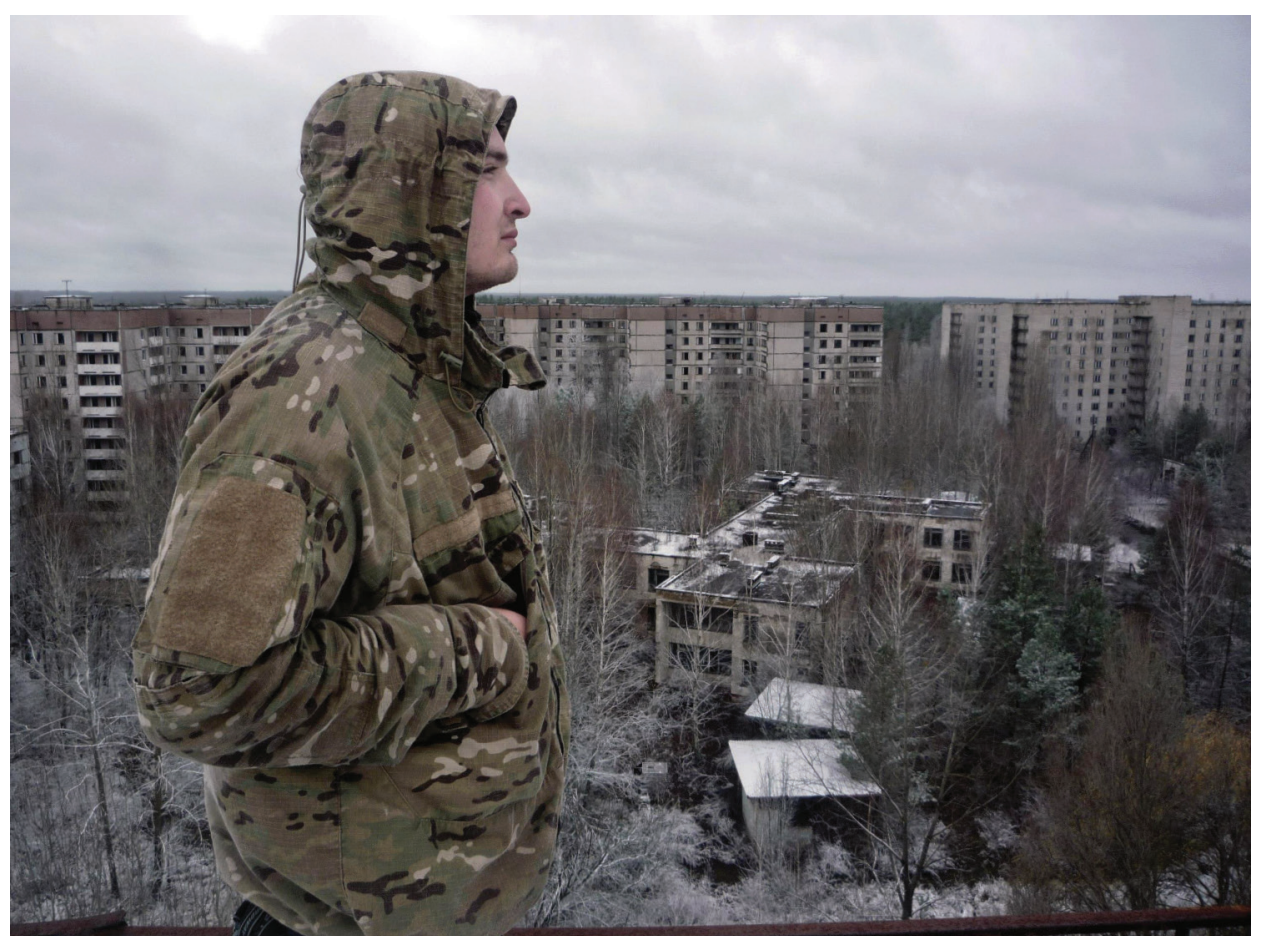

Courtesy of Kyrylo Stepanets. The Zone

teams and travel to irradiated forests surrounding the AES to explore the fire danger of large areas of the Chornobyl Exclusion Zone and its impact on health, and to analyze the trends in the rejuvenation of flora and fauna in the Zone. ${ }^{55}$

54 Andrew Leatherbarrow, “Chernobyl o1:23:40," Leatherbarrowa.exposure.co, January 25, 2014, accessed August 17, 2018, https://leatherbarrowa.exposure.co/chernobyl.

55 One such initiative is the Chernobyl Irradiated Forest Wildfire Project which is run by scientists from Ukraine and Yale University with support from the Chopivsky Family Foundation. See Chad Oliver, "Chernobyl Narrative," Campuspress (Yale University), accessed August 18, 2018, http://campuspress.yale.edu/chadoliver/cherno-narrative/. 
The Ukrainian pilgrimage (or stalkers movement) that includes predominantly young people began to develop clear contours approximately ten years ago, substantially growing within the last three or four years. ${ }^{56}$ The commercialization of the Zone, which was opened for official tourism about a decade ago, prompted various individuals to explore the Zone on their own, without restrictions and constraints imposed by the authorities. Despite the dangers of radiation and arrests by Zone security, they initially traveled to the Zone out of curiosity and for "romantic purposes," to see Chornobyl's sunrises and sunsets, unique in its beauty. The material culture of the Zone-abandoned industrial equipment and private properties, cemeteries of radioactive machines and animals, and houses and military objects - has always been the focal point for stalkers, an asset to be enjoyed and studied. One stalker has noted that the site and its material culture are "open air museums ready for its visitors. No one has to invest a penny in it; all is needed is the absence of thieves." 57

According to the young scholar and stalker Kyrylo Stepanets, the Ukrainian community of stalkers should be identified as a community of "marginal" individuals who systematically travel to the Zone, neglecting their own comfort, health, and safety, developing and shaping a special sub-culture and behavioral codes. Experienced stalkers made more than 100 trips to the Zone, considering the place a "living creature that [would] never hurt them." ${ }^{8}$ They are well adjusted to the severe weather, social and legal conditions of the Zone, and demonstrate excellent survival skills. Their creativity and innovations prevent their feet from being frozen and their souls from being hurt. ${ }^{59}$ Because of painful experiences of being detained by Zone security, the stalkers have also developed strategies that help them avoid encounters with the authorities. Today Zone security can no longer effectively control illegal nuclear tourism in the dead town of Prypiat, and its 12,00o abandoned apartments serve as temporary shelters for the stalkers. ${ }^{60}$

Many have emphasized that the perceptions of time are skewed in the Zone. Although the site of the disaster has changed beyond recognition over the last thirty years, the stalkers have an opportunity to observe a stroboscopic phenomenon of time flow in the dark cellars of the AES's medical and other facilities, where the time and the events of April 26, 1986 seem to stop and are illuminated by the stalkers' flashlights, vividly and thus horridly. The uniforms of the first firemen are still there. ${ }^{61}$ Indeed, having survived in Chornobyl, the material culture of Soviet times has dramatically changed the meanings and perceptions of time that affects people's choices and behaviors. In urban space, time passes outrageously fast, often leaving people just an instant to make a decision. In contrast, Chornobyl imposes a slow, tranquil, and "infinite" rhythm, which

\footnotetext{
56 Stepanets et al., Chernobylskaia zona, 29.

57 Stepanets et al., Chernobylskaia zona, 272.

$5^{8}$ Stepanets et al., Chernobylskaia zona, 26, 33 .

59 Stepanets et al., Chernobylskaia zona, 43.

6o Stepanets et al., Chernobylskaia zona, 220.

61 Stepanets et al., Chernobylskaia zona, 47, 51.
} 
makes people think, compare, and reflect, as the columnist for the Ukrainian newspaper Den (Day) and the author of Oformliandiia, abo prohulianka vzonu (A Formative Land, or A Walk to the Zone) Markiian Kamysh has noted. ${ }^{62}$ Interestingly, Kamysh dismisses the term "Zone," positing that "zones exist in our heads." 63 For him, Chornobyl is not a means of demarcation between order and disorder but rather an experiential resort for the lonely. Kamysh has claimed that in the Zone he personally feels extremely lonely, and thus exceptionally comfortable and happy. Loneliness is for artists and writers, not for crowds. But even for crowds, Chornobyl may become a discovery of new faculties of time and rhythm.

This post-disaster rhythm of the Zone pleases tourists, many of whom become writers and philosophers. Chornobyl and its rhythm encourage them to delve into the history of the place, awakening their creative impulses and enhancing their literary and artistic talents. They seem to be nurtured by the mysterious silence of the place, which divulges human suffering and death. People like Kamysh and Oleksandrovych, who approach the site closely, produce "living and pulsating literature" and breathtaking images of Chornobyl, not letting its civilization die. ${ }^{64}$ Importantly, the expressions of their experiences appear genuine, and thus they are valid and cogent. ${ }^{65}$ Kamysh has been identified as a writer with a unique literary voice, and Oleksandrovych — as one of the best young Ukrainian artists. ${ }^{66}$

Their creativity and tragic voices grew out of their own and other people's suffering in Chornobyl, a place which was transformed from a technological site into a machinery of destruction. Lina Kostenko has exclaimed: "Who sowed this asperity and who will harvest it?" (Khto siiav tsiu bidu i khto yii pozhne?). A new generation of Ukrainians have harvested this affliction that had been sown by their parents and grandparents. Yet after twenty trips to the Zone, their uncertainties and fear of radiation that used to penetrate their very consciousness, provoking a morose feeling of potential death, no longer bothers them. In some mysterious way, the Zone comforts them and stimulates their acute interest in both life and near death experiences. Consumed by mosquitoes and bitten by snakes, they travel to the Zone in nasty weather and bravely drink from the puddles near the deadly reactor. ${ }^{67}$ Despite the hardships of pilgrimage, these

62 Kamysh, Oformliandiia, 73 .

63 Kamysh, Oformliandiia, 73.

64 Sofiia Andrukhovych, Cover page of Oformliandiia abo prohulianka v zonu by Markiian Kamysh (Kyiv: Nora-Druk, 2015).

65 For an enlightening discussion about the genuineness and validity of human expressions and experiences, see Isaiah Berlin, "Herder and the Enlightenment," in The Proper Study of Mankind: An Anthology of Essays by Isaiah Berlin, eds. Henry Hardy and Roger Hausheer (New York: Farrar, Straus and Giroux, 2000), 389.

66 Andrukhovych, Cover page; "V Kieve otkryvaetsia vystavka luchshykh molodykh khudozhnikov Ukrainy [Opening of an Exhibition of the Best Young Artists of Ukraine]," Fokus, December 1, 2010, accessed August 17, 2018, https://focus.ua/society/15856o/.

67 Stepanets et al., Chernobylskaia zona, 33, 43. 
experiences reassert their feeling of freedom and erase uncertainties. The desolate town of Prypiat evokes nostalgia for the past in those who were born, raised, and once happy there. The site exemplifies their "semi-forgotten childhood and 'happy Soviet youth." 68 "For us, the pilgrimage to Prypiat is equally sacred as a Muslim's trip to Mecca," Stepanets has asserted. ${ }^{69}$

Neither fines nor arrests seem to prevent stalkers from appreciating the aesthetics of the Zone: "the sun shines over the dead town for everyone, but the grandeur of the sunrises belongs only to the stalkers." 70 To reach a place abandoned and forgotten by people, which still stores their possessions, the stalkers are not hesitant to wade through the tangled forests of the Zone that have overgrown railway tracks, houses, huts, and entire villages. Rusty metal beds in a former Soviet pioneer camp and the silence of empty villages and huts are sad and depressing, but according to the stalkers, their sadness is very quickly replaced with the comfort and tranquility the place conveys. Silence seems to have a therapeutic affect on the confused mind and physically exhausted body, and precisely this emotional dissonance invites the stalkers to return to the Zone. ${ }^{71}$

Yet for many stalkers like Kamysh, who were born to families of Chornobyl liquidators, the Zone has become a place where the "phallic" Chornobyl pipe (truba) (its weight was 35 o tons and its height -15 o meters) symbolizes nuclear catastrophes and personal tragedies, reminding them of their mortality and potential sudden death. ${ }^{72}$ Simultaneously, the Zone is a symbol of manhood, where their fathers matured together, saving the world from catastrophe. The French philosopher Henri Lefebvre has argued that there is something intriguing and magnetic in the "phallic verticality" of landscapes, which has a long history of being imbedded in any space and place. He has insisted that this phenomenon, at the very least, should be explained. ${ }^{73}$ Truba, the highest ventilation pipe rising over Unit 4, was demolished in late 2013 , having survived only in documentaries, photos, and memories. For many stalkers the "fall" of the main symbol of the Zone's tragedy depleted the place in many ways, and they even quit traveling to the Zone. Yet at the mercy of feelings of urgency and nostalgia, they renewed their trips to the Zone. The vanished artifact encouraged the stalkers to establish new social practices to facilitate further investigation of the Zone and its "sacred" places, ultimately shaping a new space and geography of their pilgrimage. ${ }^{74}$

68 Kamysh, Oformliandiia, 7; see also Stepanets's discussion about the aesthetics of Prypait in

Stepanets et al., Chernobylskaia zona, 232-36, 241-45, 252-55.

69 Stepanets et al., Chernobylskaia zona, 255.

70 Stepanets et al., Chernobylskaia zona, 8o.

71 Stepanets et al., Chernobylskaia zona, 132-33, 146.

72 Kamysh, Oformliandiia, 8-9, 13.

73 Henri Lefebvre, The Production of Space, trans. Donald Nicholson-Smith (Oxford, UK: Blackwell Publishing, 1991), 36.

74 Sergei Belov and Katerina Zotova, "Chernobylskaia truba ushla v istoriiu [The Chornobyl Pipe Receded into History]," Komsomolskaia pravda v Ukraine, January 9, 2014, 
Nevertheless, they appear to be uncertain whether they travel to the Zone to resurrect their dearest past or to read their own future, where nuclear disasters such as Chornobyl are possible and even likely.

Importantly, most stalkers are convinced that Chornobyl liberates people from their fears, making them reject state and nuclear violence and inciting their political activism and longing for freedom. For instance, Kamysh argues that a habit of crossing the border of the "permissible" (in this case the physical border of the Zone where surveillance mechanisms were firmly established) helps people get rid of their inner fear of authorities and their disciplinary power. He anthropologized the concept of an open air museum, attributing to Chornobyl formative functions. Inside the zone's borders, there is a space where surveillance is minimal, and thus freedom is real and "accessible." Such a place, thus, shapes people's dispositions and culture, taking them further away from the spaces of control and surveillance, which are inherently cruel and violent. ${ }^{75}$ The road to the Zone is as thorny as the road to freedom for Ukrainians, but, as another Ukrainian, filmmaker Myroslav Slaboshpytskyi, believes, these trips to the past are necessary because they are indeed trips to personal freedom and dignity.76

\section{Politics as a Formative Factor of the Chornobyl Open Air Museum}

Similar to many other thinkers, Lefebvre has argued that (social) spaces and places can never be apolitical. They are tools of thought and action, and a means of control, domination, and power. ${ }^{77}$ The state imposes itself on spaces and places, reasserting its abusive power over them, as well as over individuals and institutions that inhabit them. Although the state's domination is often overarching and violent, it is never completed. Spaces and places are also populated by other forces, and "the violence of power is answered by the violence of subversion." ${ }^{78}$ In the case of Chornobyl, the stalkers have repopulated a desolated space and place, and the balance of perennial struggle between the state and the subverted has been restored. Thirty years after the tragedy, the cataclysmic past of the Zone, recreated in millions of photographs, amplifies the lethargic feeling of popular mistrust of the authorities. For people like Oleksandrovych, the landscape of Chornobyl and its surroundings served as a powerful stimulus for investigating the reasons behind the catastrophe. Unlike obliviousness, possible clarity and answers to the question "why" help them cope with their own trauma associated with temporary displacement from the city of their birth, Kyiv.

accessed August 14, 2018, http://kp.ua/economics/432091-chernobylskaia-truba-ushla-vystoryui; Stepanets et al., Chernobylskaia zona, 322, 326.

75 Puzik's interview with Kamysh.

76 Myroslav Slaboshpytskyi, “Literatura na lito [Literature for the Summer]," Chytomo, July 11, 2016, accessed August 14, 2018, http://www.chytomo.com/books-for-summer/5-knig-yaki-raditprochitati-rezhiser-miroslav-slaboshpick.

77 Lefebvre, The Production of Space, 26.

78 Lefebvre, The Production of Space, 23. 
In addition, the politics of and around Chornobyl, experienced by at least three generations, facilitated the stalkers' interest in the Zone. Many have become aware of the Soviet politics of silence, and a nationalist movement in Ukraine in the late 1980s, triggered by Chornobyl. May 1986 became a "painful and difficult beginning of [people's] liberation from the genetic sovok-like fear of power," power that was anemic and powerless before another power - radiation, a superpower of destruction. ${ }^{79}$ For many in Ukraine, the authorities' propaganda that appeared after Chornobyl and employed the Stalinist rhetoric of "enemies," "saboteurs," "the agents of foreign secret services," and the necessity for "shock-work" had a contrary effect: it aggravated people and, as many scholars have argued, galvanized the people's mistrust of the authorities that had been stimulated by inaccurate information and pure deception forced on them by the state. ${ }^{80}$ Information about Soviet "state nuclear violence" triggered similar processes among Ukrainian youth in the 2000s. ${ }^{81}$

The stalkers learned more about the self-sacrifice of the liquidators and read the heartbreaking poetry and prose about these tragic events written by prominent Ukrainian writers. ${ }^{82}$ They realized that for the liquidators the Zone had become a lifetransforming experience. Many of the liquidators who survived the consequences of radiation claimed that they began to think differently and reconsidered their identities and values: "Chornobyl exploded my brain. I began to think." 83 Some began to think in philosophical categories, and notions such as space, place, and time became part of

79 Oksana Zabuzhko, "Postskryptum: Monoloh perekladacha pro dzvin pokynutykh khramiv [Postscript: A Translator's Monologue about the Bells of Abandoned Cathedrals]," in Vybrane lystuvannia na tli doby: 1992-2002 by Oksana Zabuzhko and Yurii Shevelov (Kyiv: Fakt, 2011), 474.

80 Serhy Yekelchyk, The Conflict in Ukraine: What Everyone Needs to Know (New York: Oxford University Press, 2015), 6o; Aliaksandr Dalhouski, Tschernobyl in Belarus: Ökologische Krise und sozialer Kompromiss (1986-1996) (Historische Belarus-Studien, Book 4) (Harrassowitz Verlag, 2015); V. Poyarkov, V., V. Kholosha, and Yu. Saenko, "Society: Social Risks After the Accident," in The Chornobyl Accident: A Comprehensive Risk Assessment by Victor Poyarkov et al., ed. George J. Vargo (Columbus \& Richland, OH: Battelle Press, 200o), 206; Wanner, Burden of Dreams, 30; Jane I. Dawson, Eco-Nationalism: Anti-Nuclear Activism and National Identity in Russia, Lithuania, and Ukraine (Durham; London: Duke University Press, 1996), 69; Alexievich, Chernobylskaia molitva, 142, 144. On the role of Chornobyl in the collapse of the Soviet Union, see Serhii Trokhym, 1986: Chornobylski khroniky [1986: The Chornobyl Chronicles] (Brusturiv: Dyskursus, 2016).

81 The concept of "state nuclear violence" was offered by the Prypiat journalist Liubov Kovalevska. See Kovalevskaia, Chernobyl. "DSP.”

82 Among them were Lina Kostenko, Ivan Drach, Borys Oliinyk, Dmytro Pavlychko, Robert Tretiakov, Valentyna Kozak, Volodymyr Shovkoshytnyi, Leonid Talalai, Viktor Baranov, and Oksana Zabuzhko.

83 Alexievich, Chernobylskaia molitva, 32, 83. Interview with Iryna and Oleksandr, former liquidators and residents of Dniprorudnyi, Zaporizhzhia oblast, Ukraine (interview was conducted by the author on March 26, 2005). 


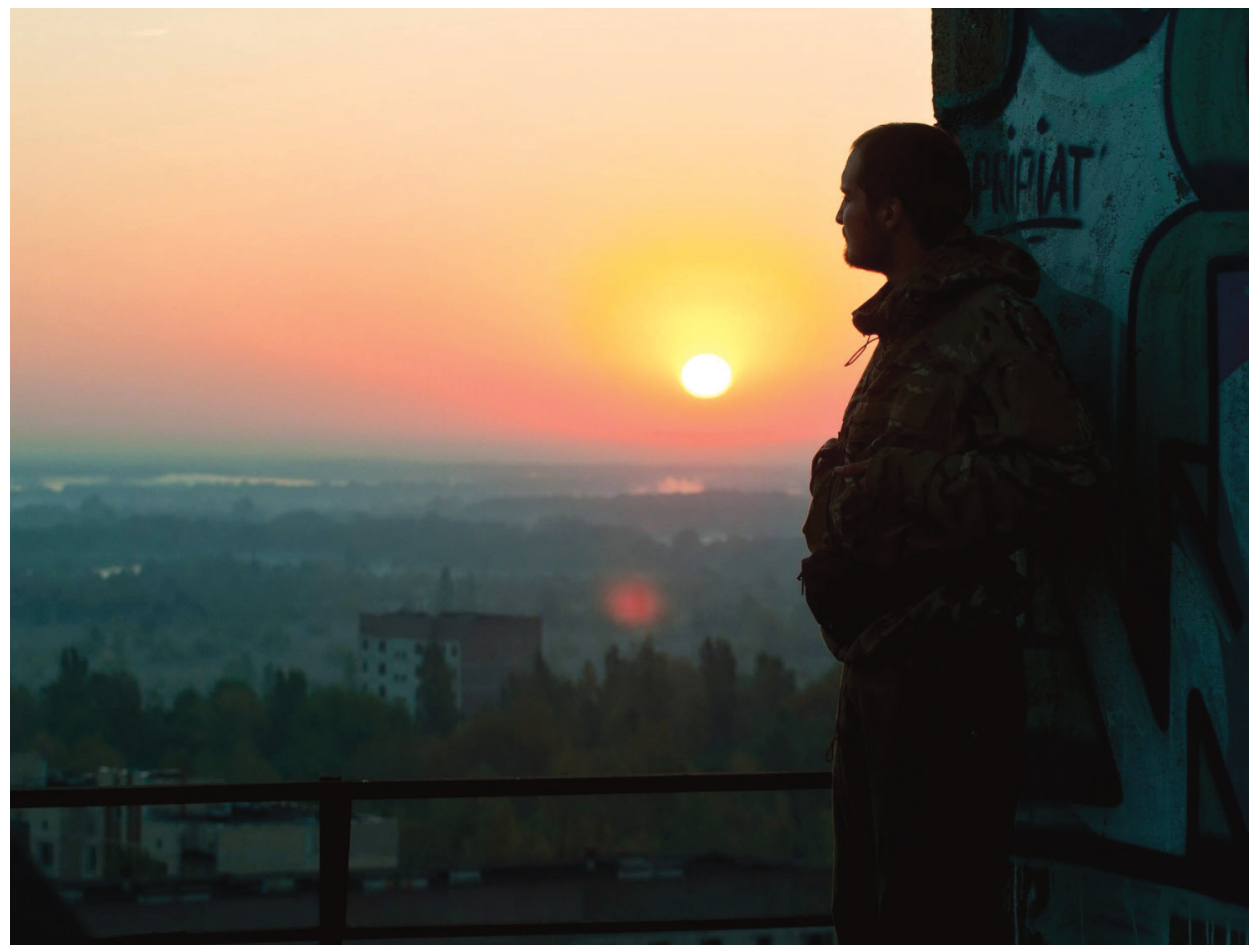

Courtesy of Kyrylo Stepanets. The Zone

their lexicon, a phenomenon familiar to the stalkers. ${ }^{84}$ In 1986, the Earth had shrunk, being absorbed by a common human tragedy, and time became an acutely relative category which could be measured and simultaneously comprehended in radionuclides' radioactive half-lives and human life-span terms: "He was 38 years old when he died because of ionizing radiation; the half-life of uranium-238 is about 4.47 billion years and that of uranium-235 is 704 million years." ${ }^{85}$ Michel Foucault would define this reality as medical uncertainty when the number and combination of probabilities which ensure certainty and affirm life are limited or often non-existent. ${ }^{86}$ The stalkers developed affinity with the Zone and its representations, internalizing human tragedies and experiencing similar medical uncertainty, using Foucault's definition.

A great wealth of literature also made the stalkers realize that medical uncertainty had been a significant part of Soviet citizens' lives. This perception had been largely shaped by the Soviet regime that had been employing medicine as a political tool for decades. ${ }^{87}$ Chornobyl further politicized medicine and science in the Soviet Union:

84 Alexievich, Chernobylskaia molitva, 36, 39.

85 Alexievich, Chernobylskaia molitva, 141.

86 Michel Foucault, The Birth of the Clinic: An Archaeology of Medical Perception, trans.

A. M. Sheridan Smith (New York: Vintage Books, 1994), 116.

87 This popular belief has been substantiated by hundreds of publications and new archival discoveries. See DAKhO R 1962/1/138/1-2, 4-8, 17. For a discussion about the use of psychiatry for political purposes, see Sidney Bloch and Peter Reddaway, Soviet Psychiatric Abuse: The Shadow over World Psychiatry (Boulder, Colorado: Westview Press, 1985); Alexander Podrabinek, Punitive Medicine, trans. Alexander Lehrman (Ann Arbor: Karoma Publishers, Inc., 1980); 
programs to alleviate the medical conditions of the liquidators officially existed but radiation disease and acute radiation syndrome caused by Chornobyl were not acknowledged. 88 The early accounts written by Yurii Shcherbak, Svetlana Alexievich, and Liubov Kovalevska provided the stalkers with a general picture of the disastrous environmental and medical consequences of Chornobyl. Moreover, these authors illuminated the social dimensions of the tragedy associated with broken families, displacement, and social inequalities, and the political reasons behind them - the Soviet state's information blockade, concealment, and manipulation that cost people their lives and wounded their pride.

The stalkers' interviews and publications reveal their acute awareness of Chornobyl politics and their close reading of literature published since 1986. Personal experiences and family memories augmented their commitment to pilgrimage and sharpened their national consciousness. In 1986, many Kyivites, including the Oleksandrovych family, made a decision to send their children away from the city to avoid their exposure to radiation. Tragically, being informed about its potential danger, Kremlin officials ordered Ukrainian authorities not to cancel the traditional May celebratory events. According to the Moscow party leadership, sowing panic among the Ukrainian population would problematize Soviet-Western relations. The order from Moscow to the Ukrainian party leadership stated that the May Day Parade in 1986 in Kyiv must be held without fail. ${ }^{89}$ Oblivious to the scale of the nuclear disaster that occurred in Kyiv's backyard, people filled the central streets of Kyiv. ${ }^{90}$ As a result, on May 1 by 5:00 PM 779 people, including 128 children, were hospitalized in Kyiv clinics. One hundred people were diagnosed with radiation disease. ${ }^{91}$ The tragic individual histories of these people are lost forever, as within days their records were falsified and they were officially categorized as generally healthy, although many of them were mortally ill. After Oleksandrovych's parents learned about the accident, they made the decision to send their three-and-half-year-old son away from the deadly radiation in Kyiv to the "Solnyshko" sanatorium in Leningrad, a place that also sheltered orphans from various

Robert van Voren, Cold War in Psychiatry: Human Factors, Secret Actors (Amsterdam; New York: Rodopi, 2010); the Vladimir Bukovsky Archive, Document 0202 (CT31/19) "About Psychiatric Care in the USSR" (February 18, 1972), 164; Olga Bertelsen, "Rethinking Psychiatric Terror against Nationalists in Ukraine: Spatial Dimensions of Post-Stalinist State Violence," Kyiv-Mohyla Humanities Journal 1 (2014): 27-76.

89 As Edward Geist has shown, after April 27, 1986, the state and party leadership "continued to oppose taking necessary steps to protect the population." See Edward Geist, "Political Fallout: The Failure of Emergency Management at Chernobyl'," Slavic Review 74.1 (2015): 124. The April 28, 1986 brief TASS announcement about the accident in Chornobyl that literally consisted of five sentences was missed by the majority of the population. An analysis of the subsequent deliberate attempt by Moscow to downplay the seriousness and the scale of the accident was offered in hundreds of publications on the topic. 
parts of the Soviet Union..$^{92}$ Traumatized by the experience, he returned to Chornobyl thirty years after the tragedy to learn more about it and about himself. ${ }^{93}$

But it is not just the politics, the Soviet practices, and the representational space of Chornobyl that disturb nuclear tourists. Soviet material culture instills ambivalent feelings among them, such as nostalgia that is associated with their carefree childhood, and resentment of Soviet modes of operation. Beyond other must-see objects such as the nuclear reactor and the town of Prypiat, there are several other sacred places in the Zone that attract the pilgrims. Among them is an object that presents cultural and historical interest for the local and international communities, known as Chornobyl-2 or Duga (arch). Duga, a gigantic Soviet over-the-horizon radar system - a row of thirty Eiffel Towers in length silent monument to the Cold War, is currently on illegal tourist maps of the majority of those who travel to Chornobyl. Hundreds of people linger daily at the base of Duga, struck by its size and grandeur. The discussion about its construction and its location were politicized before Duga emerged as a military object. The political space of Duga has been sustained throughout Ukraine's independence and was reinforced by the stalkers. ${ }^{94}$

In 1976 , the Soviets erected a facility in close proximity to the reactor, a strategically important part of the Soviet anti-ballistic missile (ABM) early-warning network, which had its own staff and infrastructure. Duga operated until December 1989 when the authorities largely abandoned it. The operating radar was extremely powerful and produced a very distinct and sharp sound, which became known in the West as the Russian Woodpeckera repetitive tapping noise at $10 \mathrm{~Hz}$ that was identified by shortwave listeners in northern America. The height of this structure is 150 meters, and the length approximately 46o meters. It is situated between what was, prior to the Chornobyl explosion, the villages of Kopachi and Dibrova. The fenced and secret place was identified as a "pioneer camp" on Soviet maps. The discovery of Duga by tourists opened up territory for speculation, myths, and new narratives about the Chornobyl explosion.

Duga was designed as an early warning long-range radar or an object-detection system for outer space surveillance to identify guided missiles and other moving objects behind the line of the horizon. This innovation was presented in 1947 by the Soviet scientist Nikolai Kabanov, an associate of the secret Scientific Research Institute no. $16 .{ }^{95}$ However, the practical application of this project is associated with the scientist

92 Private communication with Fedir Oleksandrovych (FB; May 3, 2017).

93 On trauma management, and its links to the issues of human security, identity, and suffering, see Ekatherina Zhukova, “Trauma Management: Chernobyl in Belarus and Ukraine," British Journal of Sociology 67.2 (2016): 195-215.

94 Even recently, Duga's political space has been reaffirmed as some unknown activists of procommunist views managed to install a gigantic red flag on the very top of Duga. See Stepanets et al., Chernobylskaia zona, 169, 170 . mechanisms, see A. A. Kostenko, A. I. Nosich, and I. A. Tishchenko, "Radar Prehistory, Soviet Side," IEEE XPlore, August 7, 2002, accessed August 18, 2018, https://ieeexplore.ieee.org/ 
and radio engineer Yefim Shtyren and his closest associate Vasilii Shamshin who later became Minister of Communications of the USSR. ${ }^{96}$

In November 1962, because of the escalation of the Cold War and the construction of advanced ballistic missiles by the US, the TsK and the Council of Ministers of the USSR signed a number of decrees about the creation of an effective surveillance system of outer space. These decrees facilitated the emergence of several research institutions and construction firms working on early detection of launched intercontinental ballistic missiles. "Duga-1," an over-horizon radio locator, was produced by one of these institutes, the Scientific Institute of Long-Distance Radio Communication (NII DAR), headed by Fiodor Lukin and Yefim Shtyren. The first experimental radar, constructed in 1964 near the village of Kalynivka in the Mykolaiiv oblast (Ukraine), was able to detect a rocket launched 3,00o kilometers away from the Soviet kosmodrom Baikonur. In June 1965, the authorities decided to build an experimental truncated version of the radar system "Duga-2" in Kalynivka and by late 1966 the project was completed. Although the testing period was rather short and the reliability of the system was not completely clear, the Soviet government made a decision to construct a more advanced "Duga" system in Chornobyl (Ukraine) and Komsomolsk-na-Amure (Russia). The radar in Chornobyl was oriented toward northern America through the North Pole, and the system was supposed to detect single and multiple targets within 9,00o kilometers. ${ }^{97}$ Early detection of launched missiles provided the Soviets with a response time of approximately 30 minutes to neutralize a target.

document/959396/; Raymond C. Watson, Jr., Radar Origins Worldwide: History of Its Evolution in 13 Nations through World War II (Bloomingtom, IN: Trafford Publishing, 20o9); John Erickson, "Radio-Location and the Air Defense Problem: The Design and Development of Soviet Radar," Science Studies 2.3 (1972): 241-63; Robert Morris Page, The Origin of Radar (New York: Doubleday Anchor, 1962); Greg Goebel, "The British Invention of Radar," Airvectors, accessed August 17, 2018, http://vc.airvectors.net/ttwiz_o1.html; V. S. Kristal, Optimalnaia obrabotka radiolokatsionnykh signalov [An Optimal Analysis of Radiolocation Signals], Urss.ru, 2014, accessed August 18, 2018, http://urss.ru/PDF/add_ru/189302-1.pdf; "Chernobyl-2, on zhe ZGRLS 'Duga' [Chornobyl-2, or the ZGRLS 'Duga'],' Livejournal (Masterok), April 28, 2013, accessed August, 2018, http://masterok.livejournal.com/918653.html.

96 In designing a powerful over-horizon radar, they were assisted by young Soviet scientists Efir Shustov and Boris Kukis. See Shamshin's biography in "Vasilii Shamshin," Peoples.ru, accessed August 15, 2018, http://www.peoples.ru/state/minister/russia/vasiliy_shamshin/; Aleksandr Babakin, "Zagorizontnaia epopeia [An Over-Horizon Epopee]," Vozdushno-kosmicheskaia oborona, January 1, 2001, accessed August 15, 2018, militaryrussia.ru/forum/download/file. php?id=39915.

The most knowledgeable radar engineers contributed to the final design of the systemFrants Kuzminskii, Vladimir Vasiukov, Vasilii Shamshin, Yefim Shtyren and Efir Shustov. "Radiolokatsionnye stantsii razvedki dalnego obnaruzheniia [Radiolocation Surveillance Stations for Distant Monitoring]," Sovershenno Sekretno - Osobaia Papka, February 20, 2016, accessed August 17, 2018, http://ss-op.ru/reviews/view/61; “Chernobyl-2," Livejournal (Masterok). 
The first series of testing electromagnetic signals from Chornobyl-2 was launched on July 4, 1976, and was detected immediately not only by special surveillance equipment but also by amateur radio operators all over the globe. The Russian Woodpecker employed radio frequencies that were guarded by international treaties on radio propagation, including the international bandplan and interference rules for medium wave AM broadcasting. ${ }^{98}$ Not surprisingly, the Soviet government dismissed complaints by the U. S., British and Canadian governments about the Russians violating these treaties. Soviet officials also mocked the theories of the powerful psychotropic effect of the signals on people's behavior which, according to some claims advanced by the West, were able to control people's actions and thoughts. ${ }^{99}$

The most fascinating aspect of the monster object is that the system, carefully designed by the most brilliant Soviet scientists, was dysfunctional at its birth. In other words, the radar whose construction and installation cost approximately seven billion rubles was largely ineffective. ${ }^{100}$ To simplify the matter, the system could not function smoothly because of the systematic interference of a natural phenomenon - the Northern Lights. The dissonance between substantial investments into this project by the Soviets and Duga's a priori dysfunctionality advanced Oleksandrovych's suspicion. A frequent guest at Duga, he launched a private investigation of the Chornobyl accident which seemed mysterious to him. Duga and its unfortunate history became part of his narrative about the possible causes of the Chornobyl disaster.

After collecting oral histories from those who worked for Duga and the AES before the accident, Oleksandrovych concluded that the Chornobyl explosion was a carefully designed plan which was executed by Moscow to protect Vasilii Shamshin, a Moscow bureaucrat who was one of the founders of the radar system, including Chornobyl-2. According to Oleksandrovych, the visit of a Moscow commission to Chornobyl-2 that had been scheduled immediately after the explosion of Unit 4 never materialized because of the disaster. The flaws of the radar system were about to be discovered and someone would have to pay for the unprecedented waste of resources invested in the project without sufficient theoretical preparation and by skipping the most crucial experimental stages of the project. ${ }^{101}$ Oleksandrovych's supposition that the explosion was a cover up operation designed in Moscow has been explained in the documentary

98 For a discussion about these international agreements, see Edward Wenk, Jr., Making Waves:

Engineering, Politics, and the Social Management of Technology (Urbana; Chicago: University of Illinois Press, 1995), 62-66. A bandplan refers to the modes and types of allocations within each range of frequencies, and is typically set by international agreements, national regulations, or agreements between amateur radio operators.

See the images of Chernobyl-2 in Stepanets et al., Chernobylskaia zona, 150-71. "Sekretnyi obekt 'Chernobyl-2' raskryl svoi tainy [The Secret Object 'Chornobyl-2' Revealed Its Secrets]," InoTV, April 22, 2011, accessed August 15, 2018, https://russian.rt.com/ inotv/2O11-04-22/Sekretnaya-laboratoriya-CHernobilya-raskrila-svoi. 
The Russian Woodpecker, which remains only a supposition. It seems to be consistent with Kravchuk's analysis, although sceptics reject both attempts at challenging the official accidental version of the tragedy, rightfully identifying them as speculations. Without solid evidence, Oleksandrovych's theory about the causes of the Chornobyl accident seems to fall into the category of conspiracy theories that naturally emerge in societies in which the truth is chronically concealed and suppressed. But what is remarkable about Oleksandrovych's narrative is that it connotes the drama of children born in the early and mid-1980s who were displaced to sanatoriums and orphanages and who today, as adults, seek an answer to the question - why? "Their childhood was stolen from them"; they had to grow up in places other than their native lands, another stalker explains. ${ }^{102}$

Omitting, however, the context and the content of conspiracy theory discussions, Oleksandrovych's search for truth was certainly inherited from other Ukrainians whose aspirations to learn more about Ukraine's past and their hunger for truth were formed during the Khrushchev Thaw. Thirty years ago, in his poem "Mii Chornobyl" (My Chornobyl), the Ukrainian poet Robert Tretiakov denounced state nuclear violence and lies that accompanied it. He rejected the possibility of the Ukrainians' collective death. He refused to search for analogies and rhymes for Chornobyls and Hiroshimas, and lamented that his own life and values did not exemplify the highest moral principle — the truth. ${ }^{103}$ Similarly, a decade later, in 1996, Dmytro Pavlychko has posited that

the Chornobyl tragedy is the result of the supremacy of the system of lies that was the basis of the Russian-Soviet empire. Lies were pandemic. Children considered themselves the happiest children in the world. Academics believed that the wisdom of the world lay in the quotations from Lenin's and Marx's works. Although slaves, [Soviet] peoples considered themselves free. Yet one could not force the atom to lie! It took revenge for people placing it in horrific conditions of survival. The reason for the Chornobyl tragedy were the humiliating and deceptive circumstances of human life. ${ }^{104}$

In tune with his predecessors, Oleksandrovych insists that today's Ukraine absorbed the Soviet legacies and lies, becoming routine and invisible like radiation and devouring people from the inside. He referred to Chornobyl as the "atomic heart of the USSR" and to Duga as "the eye of Moscow" whose powers circulated through the minds of the Ukrainians, through local politics, and through Ukraine's history and culture as

102 Stepanets et al., Chernobylskaia zona, 138.

103 Robert Tretiakov, Vybrana liryka [Selected Lyrics] (Kharkiv: Maidan, 1995), 5 ०.

104 Dmytro Pavlychko, Holosy moho zhyttia: Statti, vystupy, interviu. Dokumenty [The Voices of My

Life: Articles, Talks, Interviews. Documents] (Kyiv: Osnovy, 2013), 433. 
a whole. ${ }^{105}$ He gravitates toward the idea that Chornobyl was a pre-planned unsolved crime which perpetuated violence, secretiveness, and uncertainty in contemporary Ukraine. According to Oleksandrovych, Soviet traditions and technologies of terrorism, intimidation, fear, and chaos imported from the Kremlin are very much alive and active in Ukraine, and their roots should be traced to the Soviet era and the events of $1986 .{ }^{106}$ During the Ukrainian Revolution of Dignity in 2013-2014, Oleksandrovych insisted that the Soviet Union was coming back, predicting in late December of 2013 the Russian invasion of Ukraine. ${ }^{107}$

Crucially, the political vigor of the Zone invites young Ukrainians to revisit the Soviet past, and regardless of their beliefs, they thoroughly document the vanishing Soviet culture, creating a gallery of images, paintings, and texts. Moreover, the most faithful pilgrims create a visual history of each location in the Zone, which demonstrates the gradual destruction and deterioration of the Zone's material culture and the evidence of Soviet politics embedded in it. The forces of nature, vandalism, and the activities of marauders inevitably change the look of the Zone. But its images persistently captured by the stalkers sustain the truth about Ukraine's colonial past. Stepanets left for humanity his unique photos of the site and a written spatial history of the place; Kamysh shared his impressions about the Zone through original prose that simultaneously constituted a literary text and a historical document; and Oleksandrovych provided us with his vision of the Zone and his dazzling art which through the flames of Chornobyl established a conceptual and mnemonic connection between the Soviet past and Ukraine's present and future.

The pilgrimage to the Zone indeed transformed Chornobyl into an open air museum. Its aesthetics and politics produced a new culture, which escapes from the panopticistic culture of conventional museums and exhibitions. Through the stalkers' eyes and activities, this unusual museum opened up to the world the archaic technology associated with Soviet modernity, and its ideological contents consistent with imperial practices, namely - control, terror, surveillance, and corruption. Importantly, this museum encourages people to see beyond objects, such as the destroyed town of Prypiat and the failed towers of Duga ("the king of Anti-nature," using Lina Kostenko's metaphor). The space of this open air museum is akin to an interactive map that provides images with answers embedded in them. This space has shaped Oleksandrovych's art, Stepanets's dispositions, and Kamysh's self-expression and has defined who they are, but most importantly, it has provided them with an opportunity to make a personal choice, an impossible prospect when this space was

105 Katerina Lebedeva, “Rezhiser filma 'Russkii diatel' Grasia: Avariia na ChAES sviazana s Yevromaidanom [The Director of the Documentary 'Russian Woodpecker' Gracia:

The Explosion at the AES Is Linked to the Euromaidan]," Gordon, May 11, 2015, accessed August 14, 2018, http://gordonua.com/publications/rezhisser-filma-russkiy-dyatel-chad-grasia-avariyana-chaes-svyazana-s-evromaydanom-79401.html.

106 Kirillova, "Chernobylskuiu AES”; Lebedeva, "Rezhiser filma 'Russkii diatel.”

107 See Chad Gracia’s interview in Lebedeva, "Rezhiser filma 'Russkii diatel.” 
Soviet. The majority of stalkers have become nationally conscious patriots, joining the demonstrators at the Kyiv Maidan during the 2013-2014 Revolution of Dignity.

\section{Epilogue}

The stalkers offer us intimate knowledge about one of the most famous "spontaneous" open air museums in the world - Chornobyl. They provide us with what Clifford Geertz would identify as a "thick description" of the place and its artifacts, extending our imagination about people's suffering during the era of Chornobyl and thus enhancing our understandings of the larger Soviet culture of which many of us were a part. ${ }^{108}$ By intellectually and physically returning to the desolate Exclusion Zone, they sought to discover its meaning, and the truth about the nuclear cataclysm and Ukraine's history, a move provoked by their family backgrounds and their individual tragic memories of the past. But as many stalkers repeated on several occasions, having sought the meaning of the place, they discovered something different, no less important. Through their personal experiences in Chornobyl, they discovered their new identities and new creative impulses that inspired and shaped their lives and art. Their creative writings and paintings reflect the unsayable - the horror of a nuclear disaster, offering the emotional cartography of the place. Their trips to Ukraine's past, where time seems to stop in 1986, allowed them to more acutely perceive their present, and to imagine their future.

The aesthetics and politics, intrinsic elements of this place, invite the stalkers to follow in the steps of Shcherbak, Alexievich, Kovalevska and many other intellectuals whose texts attempted to predict Ukraine's post-Chornobyl future and to accurately convey the degree of suffering of those who worked on the front line dealing with the early stage of the catastrophe. When in the autumn of 1986 Shcherbak visited the Poliskyi district (the villages of Vilcha and Zelena Poliana), he realized that he was looking into the eyes of the future with the "new demands of the atomic age [which] were entering the consciousness and daily life and customs of people." 109 Geiger counters (dosimeters), displacement, human suffering, and feelings of uncertainty, insecurity, and frustration became part of people's lives and the space in which they existed. ${ }^{110}$ Thirty years after the tragedy, we learned that the Chornobyl open air museum has a transnational meaning and that human suffering associated with Chornobyl is

108 For the concepts of "thick description" and "local knowledge," see Clifford Geertz,

The Interpretation of Cultures (London: Fontana, 2000); and Clifford Geertz, Local Knowledge:

Further Studies in Interpretive Anthropology (New York: Basic Books, 1983).

109 Shcherbak, Chernobyl, 4. Similarly, David R. Marples attempted to see the future through the prism of Chornobyl. He was correct, arguing in 1986 that Chornobyl would not be the last such nuclear disaster. See Marples, Chernobyl and Nuclear Power in the USSR, 180.

110 Adriana Petryna identified these uncertainties as "new biological uncertainties." For a related concept of "biological citizenship," see Adriana Petryna, Life Exposed: Biological Citizens after Chernobyl (Princeton; Oxford: Princeton University Press, 2002). 
not locked in the past - it transcends space and time, becoming part of a history of state nuclear violence associated with inhumanity and the cynicism of non-democratic regimes.

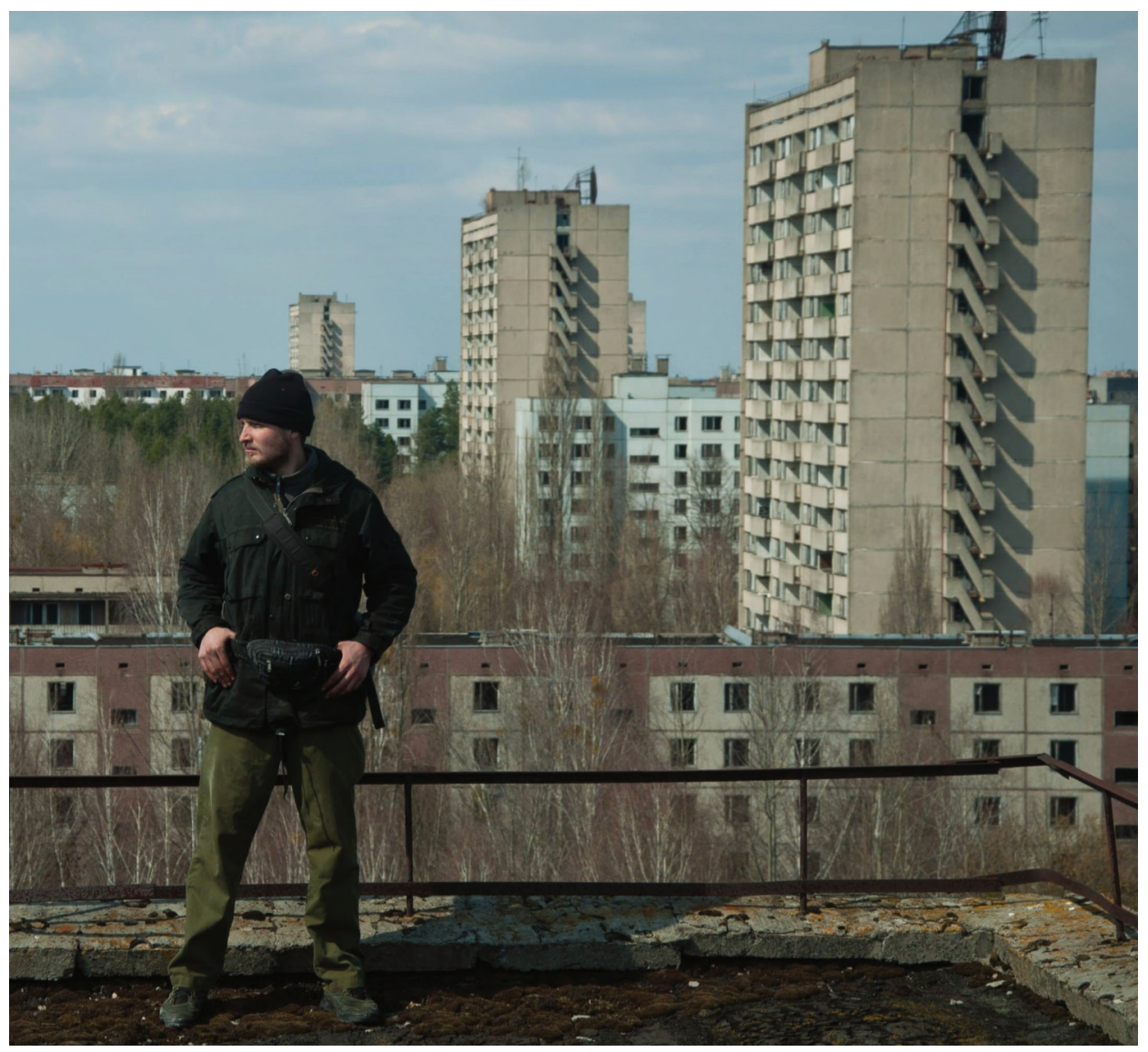

Courtesy of Kyrylo Stepanets. The Zone

Importantly, Chornobyl, its landscape and history contributed to the coherence of self-identification of people like Stepanets, Kamysh, and Oleksandrovych. At the moment of crisis, such as the Ukrainian revolution of 2013-2014, their selfidentifications were enlightened by patriotic feelings and anti-imperial sentiments that were amplified by the Soviet production of the lifeless space observed in Chornobyl. Beyond intellectual commitment and efforts invested in research, and environmental and political activism, the stalkers strive to liberate themselves from spatial and mental enclosures, torturous memories, and the "ghosts of the Soviet past," as Oleksandrovych has characterized his own quest for the truth about Chornobyl and his own identity. The historicity and the material culture of Chornobyl enhance the stalkers' acute awareness of the pervasiveness of Soviet legacies, reducing the possibility of the subversion of their identities. They persistently search for closure, which ultimately implies freedom from oppressive state and nuclear violence. Like for Alexievich, who identified Chornobyl as a mystery for the twenty first century, and for the British writer and historian Piers Paul Read, who argued that "the consequences of the accident remained as uncertain 
as the cause," for the stalkers, any historical interpretation of Chornobyl is fraught with incompletion, inaccuracy, and uncertainty. ${ }^{111}$

Over the past decade, illegal nuclear tourists mastered and appropriated the Chornobyl Zone, transforming it into a museum and a representational space which human imagination seeks to change, understand and explain. This place lives through its images and symbols, constantly changing through the spatial practices of its inhabitants. ${ }^{112}$ Ruminating about representational space, Lefebvre has suggested that it is always alive, because it speaks: "it may be directional, situational or relational, because it is essentially qualitative, fluid and dynamic." 113 As we have seen, the Zone is fluid, in turn changing people's views and perceptions and inviting them to take a look at history in a new light. Precisely this factor incites us to study not only the history of this open air museum but also the history of its representations in conjunction with human practices and ideology. The products of representational spaces such as Chornobyl are unique symbolic works that form new aesthetic and ideological trends in society. Importantly, these works signify the polysemic exploration of human limitations, power, and inner self, an exercise that, among other things, helps transmit knowledge about secret and regimented places such as the Chornobyl open air museum. The producers of its contested space, the stalkers, offer their audiences a choice - to embrace or reject it.

Critically, through persistence, art, and pilgrimage to the Zone, the stalkers keep dead towns, like Prypiat, and memories about them alive. They make Prypiat worth something — at the very least, worth remembering. ${ }^{.14}$ The Chornobyl open air museum is a legally closed area and a dangerous place, and its rigid rules established by the authorities and nature certainly regiment people's behavior there, no matter how free the stalkers feel there. However, its vanishing material culture, mystery, and unpredictability continue to lure them to examine the roots of their fears, anxieties, and uncertainties, which appears to be the only way to free themselves. "Life is a challenge and often dictates where to walk, how to live, and what air to breath," but only in the Zone "life is not passing by me," Kamysh has ruminated. ${ }^{115}$ People, like Kamysh, experience history as nostalgia and the future as freedom, creating their own rules in the Zone and a new code of social behavior. For them, the Chornobyl open air museum is a horizon disappearing swiftly behind them, and through their routine trips to the Zone, they maintain its spatial and epistemological continuity.

Critics of open air museums who claim that such places lack authenticity and accuracy in recreating the past might discover an interesting phenomenon in the

111 Piers Paul Read, Ablaze: The Story of the Heroes and Victims of Chernobyl

(New York: Random House, 1992), 344.

For a discussion of the perceived-conceived-lived triad in spatial terms, see Lefebvre,

The Production of Space, 38-46.

Lefebvre, The Production of Space, 42.

114 Stepanets et al., Chernobylskaia zona, 211-12.

115

Kamysh, Oformliandiia, 105-07. 
Chornobyl case: the authenticity of this place's past is unintentional and sustained through a "Brownian motion" of stalkers and nuclear tourists who historicize and preserve the dead surroundings of the AES by photographing, cartographing, exploring, discovering, and building, activities that facilitate the distribution of knowledge about one of the most secret objects in Soviet Ukraine. ${ }^{116}$ The initial accident, the tragedy of millions of people provoked by it, and the subsequent pilgrimage to the Chornobyl Zone have placed this museum on the map of human suffering, and its authenticity shines through millions of old and new photos of the Zone and its unearthing and tragic symbolic representations, serving as cultural bridges between generations. The cultural continuity of the Chornobyl museum is still awaiting more fundamental analyses, but its current spatial assessment reveals the significance of Chornobyl's space for Ukrainians, which arms them with some code to a better understanding of the past and of the histories of individual lives, interrupted by the nuclear explosion in 1986. ${ }^{117}$ Possibly, future research will repackage, reconceive and rearticulate the story and the roots of the Chornobyl tragedy, but the full truth might never be learned. The only certainty about Chornobyl and the adjacent territories seems to be linked to temporal factors: these places are not going to be habitable for a long time where safe resettlement is possible. ${ }^{118}$ As a consequence, Chornobyl will remain an open air museum for quite some time, attracting individuals longing for knowledge and freedom, and Chornobyl's meaning will always be negotiated because, as is symptomatic of other places and times, there is no single "authentic" truth of the place. ${ }^{119}$ Ultimately, Chornobyl is polysemic in nature, always inviting interpretations.

116 In physics, Brownian motion refers to the random motion of particles suspended in a fluid resulting from their collision with the fast-moving molecules in the fluid.

117 Oksana Zabuzhko has ruminated about the mystery of individual lives that cannot be decoded through official documents and myths. An attempt at insight (a look from "inside") is necessary to realize the myriads of "little things" that people usually take with them to the grave, when the code to understanding them is lost forever. See Zabuzhko, Muzei pokynutykh sekretiv, 32-33.

118 Andrew L. Jenks correctly argues that those who live even hundreds of kilometers from the reactor cannot be sure about the safety of their environments - "the truth [about the dangers of possible contamination] can never be known." See Andrew L. Jenks, Perils of Progress: Environmental Disasters in the Twentieth Century (New York: Prentice Hall, 2011), 125. For a discussion about the deadly influence of radiation on human blood cells, see Kate Brown, Plutopia: Nuclear Families, Atomic Cities, and the Great Soviet and American Plutonium Disasters (New York: Oxford University Press, 2013). See also Lewis Siegelbaum's interview with Kate Brown in ASEEES NewsNet 55. 2 (2015): 7.

119 Doreen Massey, "Double Articulation: A Place in the World," in Displacements: Cultural Identities in Question, ed. Angelika Bammer (Bloomington; Indianapolis: Indiana University Press, 1994), 119 . 


\section{Bibliography}

Agamian, Mariam. "Chad Grasia: Moi film ne o Chernobyle, a o cheloveke [My Film is not About Chornobyl but About a Person]." Ukrainska pravda, January 25, 2016. Accessed August 17, 2018. https://life.pravda.com.ua/culture/2016/o1/25/206996/.

Alexievich, Svetlana. Chernobylskaia molitva: Khronika budushchego [Chernobyl Prayer: A Chronicle of the Future]. Moscow: Vremia, 2016.

Anderson, Jay. Time Machines: The World of Living History. Nashville, TN: American Association for State and Local History, 1984.

Andrukhovych, Sofiia. Cover page of Oformliandiia abo prohulianka vzonu by Markiian Kamysh. Kyiv: Nora-Druk, 2015.

Babakin, Aleksandr. "Zagorizontnaia epopeia ["An Over-Horizon Epopee].” Vozdushnokosmicheskaia oborona, January 1, 2001. Accessed August 15, 2018. https:// militaryrussia.ru/forum/download/file.php?id=39915.

Bar'yakhtar, V., V. Poyarkov, V. Kholosha, and N. Shteinberg. "The Accident: Chronology, Causes, and Releases." In The Chornobyl Accident: A Comprehensive Risk Assessment by Victor Poyarkov et al., edited by George J. Vargo, 5-34. Columbus \& Richland, OH: Battelle Press, 2000.

Bar'yakhtar, V., V. Poyarkov, V. Kholosha, and V. Kukhar' “The Shelter: Containing the Destroyed Reactor." In The Chornobyl Accident: A Comprehensive Risk Assessment by Victor Poyarkov et al., edited by George J. Vargo, 35-84. Columbus \& Richland, $\mathrm{OH}$ : Battelle Press, 2000.

Bates, Alan T. "Addressing Existential Suffering." BC MedicalJournal 58.5 (2016): 268-73. Belov, Sergei, and Katerina Zotova. "Chernobylskaia truba ushla v istoriiu [The Chornobyl Pipe Receded into History]." Komsomolskaia pravda v Ukraine, January 9, 2014. Accessed August 14, 2018. http://kp.ua/economics/432091-chernobylskaiatruba-ushla-v-ystoryui.

Bennett, Tony. The Birth of the Museum: History, Theory, Politics. London: Routledge, 1995.

Berlin, Isaiah. "Herder and the Enlightenment." In The Proper Study of Mankind: An Anthology of Essays by Isaiah Berlin, edited by Henry Hardy and Roger Hausheer, 359-435. New York: Farrar, Straus and Giroux, 2000.

Bertelsen, Olga. "Rethinking Psychiatric Terror against Nationalists in Ukraine: Spatial Dimensions of Post-Stalinist State Violence." Kyiv-Mohyla Humanities Journal 1 (2014): 27-76.

Bloch, Sidney, and Peter Reddaway. Soviet Psychiatric Abuse: The Shadow over World Psychiatry. Boulder, Colorado: Westview Press, 1985.

Bovin, Aleksandr. 5 let sredi yevreev i midovtsev, ili Izrail iz okna rossiiskogo posolstva (iz dnevika) [Five Years Among Jews and MID People, or Israel From a Window of the Russian Embassy (From the Diary)]. Moscow: Zakharov, 2000.

Brown, Kate. Plutopia: Nuclear Families, Atomic Cities, and the Great Soviet and American Plutonium Disasters. New York: Oxford University Press, 2013. 
"Chernobyl-2, on zhe ZGRLS 'Duga' [Chornobyl-2, or the ZGRLS 'Duga']." Livejournal (Masterok), April 28, 2013. Accessed August, 2018. http://masterok.livejournal. com/918653.html.

Dalhouski, Aliaksandr. Tschernobyl in Belarus: Ökologische Krise und sozialer Kompromiss (1986-1996). Historische Belarus-Studien, Book 4: Harrassowitz Verlag, 2015.

Dawson, Jane I. Eco-Nationalism: Anti-Nuclear Activism and National Identity in Russia, Lithuania, and Ukraine. Durham; London: Duke University Press, 1996.

Erickson, John. "Radio-Location and the Air Defense Problem: The Design and Development of Soviet Radar." Science Studies 2.3 (1972): 241-63.

"Fallout Studies: Recent and Current Studies of Radioactive Fallout." National Cancer Institute. Accessed May 16, 2017. https://dceg.cancer.gov/research/what-we-study/ fallout-studies.

Foucault, Michel. Discipline and Punish: The Birth of the Prison. Translated by Alan Sheridan. New York: Vintage Books, 1995.

Foucault, Michel. The Birth of the Clinic:An Archaeology of MedicalPerception. Translated by A. M. Sheridan Smith. New York: Vintage Books, 1994.

Geertz, Clifford. Local Knowledge: Further Studies in Interpretive Anthropology. New York: Basic Books, 1983.

Geertz, Clifford. The Interpretation of Cultures. London: Fontana, 2000.

Geist, Edward. "Political Fallout:The Failure of Emergency Management at Chernobyl'." Slavic Review 74.1 (2015): 104-26.

Gessen, Keith. “Translator's Preface." In Voices from Chernobyl: The Oral History of a Nuclear Disaster by Svetlana Alexievich, ix-xiii. Translated by Keith Gessen. New York: Picador, 2005.

Goebel, Greg. "The British Invention of Radar." Airvectors. Accessed August 17, 2018. http://vc.airvectors.net/ttwiz_ou.html.

Gracia, Chad. The Russian Woodpecker. Documentary. 2015.

Gunn, Simon. History and Cultural Theory. London: Pearson Education Limited, 2006.

Jenks, Andrew L. Perils of Progress: Environmental Disasters in the Twentieth Century. New York: Prentice Hall, 2011.

Kamysh, Markiian. Oformliandiia abo prohulianka v zonu [A Formative Land, or A Walk to the Zone]. Kyiv: Nora-Druk, 2015.

Kipling, Rudyard. Stalky \& Co., 1st ed. London: Macmillan, 1899.

Kirillova, Ksenia. "Chernobylskuiu AES vzorvali po prikazu iz Moskvy? [Was the Chornobyl AES Blown up on Moscow's Order?].” Vse Media, March 31, 2016. Accessed August 15, 2018. http://vse.media/chernobyilskuyu-aes-vzorvali-poprikazu-iz-moskvyi/.

Kostenko, A. A., A. I. Nosich, and I. A. Tishchenko. "Radar Prehistory, Soviet Side." IEEE XPlore, August 7, 2002. Accessed August 18, 2018. https://ieeexplore.ieee.org/ document/959396/.

Kovalevskaia, Liubov. Chernobyl. "DSP." Posledstviia Chernobylia [Chornobyl. "DSP." The Consequences of Chornobyl]. Kyiv: Abris, 1995. 
Kowalczyk, Karolina. Official website. Accessed August 13, 2018. http://www.karolinaart. com/karolina-art.

Kozlova, Anastasiia (interview with Nikolai Kravchuk). "Tragediia v Chernobyle byla umyshlena! [The Tragedy at Chornobyl Was Planned!]." Newsland, July 23, 2013. Accessed August 17, 2018. https://newsland.com/community/88/content/ tragediia-v-chernobyle-byla-umyshlena/2207091.

Kravchuk, Nikolai. Zagadka Chernobylskoi katastrofy (Opyt nezavisimogo issledovaniia) [The Mystery of the Chornobyl Catastrophe: Experience of Independent Research]. Moscow: "AIRO-XXI," 2011.

Kristal, V. S. Optimalnaia obrabotka radiolokatsionnykh signalov [An Optimal Analysis of Radiolocation Signals]. Urss.ru, 2014. Accessed August 18, 2018, http://urss.ru/ PDF/add_ru/189302-1.pdf.

Leatherbarrow, Andrew. "Chernobyl o1:23:40." Leatherbarrowa.exposure.co, January 25, 2014. Accessed August 17, 2018. https://leatherbarrowa.exposure.co/chernobyl.

Lebedeva, Katerina. “Rezhiser filma 'Russkii diatel' Grasia: Avariia na ChAES sviazana s Yevromaidanom [The Director of the Documentary 'Russian Woodpecker' Gracia: The Explosion at the AES Is Linked to the Euromaidan]." Gordon, May 11, 2015. Accessed August 14, 2018. http://gordonua.com/publications/rezhisser-filmarusskiy-dyatel-chad-grasia-avariya-na-chaes-svyazana-s-evromaydanom-79401. html.

Lefebvre, Henri. The Production of Space. Translated by Donald Nicholson-Smith. Oxford, UK: Blackwell Publishing, 1991.

Los', I., and V. Poyarkov. "Individuals: Accident Remediation Personnel and Public Doses." In The Chornobyl Accident: A Comprehensive Risk Assessment by Victor Poyarkov et al., edited by George J. Vargo, 181-204. Columbus \& Richland, OH: Battelle Press, 2000.

Marples, David R. Chernobyl and Nuclear Power in the USSR. New York: St. Martin's Press, 1986.

Massey, Doreen. "Double Articulation: A Place in the World." In Displacements: Cultural Identities in Question, edited by Angelika Bammer, 110-21. Bloomington; Indianapolis: Indiana University Press, 1994.

Medvedev, Grigori. The Truth about Chernobyl. Translated by Evelyn Rossiter. New York: Basic Books, Inc., 1991.

Medvedev, Zhores. The Legacy of Chernobyl. New York; London: W. W. Norton \& Company, 1992.

Oliver, Chad. "Chernobyl Narrative." Campuspress (Yale University). Accessed August 18, 2018. http://campuspress.yale.edu/chadoliver/cherno-narrative/.

Page, Robert Morris. The Origin of Radar. New York: Doubleday Anchor, 1962.

Pavlychko, Dmytro. Holosy moho zhyttia: Statti, vystupy, interviu. Dokumenty [The Voices of My Life: Articles, Talks, Interviews. Documents]. Kyiv: Osnovy, 2013.

Petryna, Adriana. Life Exposed: Biological Citizens after Chernobyl. Princeton; Oxford: Princeton University Press, 2002. 
Plokhy, Serhii. Chernobyl: The History of a Nuclear Catastrophe. New York: Basic Books, 2018.

Podrabinek, Alexander. Punitive Medicine. Translated by Alexander Lehrman. Ann Arbor: Karoma Publishers, Inc., 198o.

Poyarkov, V. "Introduction." In The Chornobyl Accident: A Comprehensive Risk Assessment by Victor Poyarkov et al., edited by George J. Vargo, 1-4. Columbus \& Richland, OH: Battelle Press, 2000.

Poyarkov, V., V. Kholosha, and Yu. Saenko. "Society: Social Risks After the Accident." In The Chornobyl Accident: A Comprehensive Risk Assessment by Victor Poyarkov et al., edited by George J. Vargo, 205-08. Columbus \& Richland, OH: Battelle Press, 2000.

Puzik, Valerii (interview with Markiian Kamysh). Litaktsent, January 5, 2016. Accessed August 18, 2018. http://litcentr.in.ua/blog/2016-01-05-78.

"Radiolokatsionnye stantsii razvedki dalnego obnaruzheniia [Radiolocation Surveillance Stations for Distant Monitoring]." Sovershenno Sekretno-Osobaia Papka, February 20, 2016. Accessed August 17, 2018. http://ss-op.ru/reviews/ view/61.

Read, Piers Paul. Ablaze: The Story of the Heroes and Victims of Chernobyl. New York: Random House, 1992.

Rentzhog, Sten. Open Air Museums: The History and Future of a Visionary Idea. Stockholm: Carlssons; Ostersund: Jamtli, 2007.

Riley, Chloe. "For Polish Artist, Chernobyl Nuclear Disaster Hits Close to Home." Chicago Tonight, April 18, 2016. Accessed August 13, 2018. https://chicagotonight. wttw.com/2016/o4/18/polish-artist-chernobyl-nuclear-disaster-hits-close-home.

Schmid, Sonja D. Producing Power: The Pre-Chernobyl History of the Soviet Nuclear Industry (Inside Technology). 1st ed. Cambridge, MA: The MIT Press, 2015.

"Sekretnyi obekt 'Chernobyl-2' raskryl svoi tainy [The Secret Object 'Chornobyl-2' Revealed Its Secrets]." InoTV, April 22, 2011. Accessed August 15, 2018. https:// russian.rt.com/inotv/2O11-04-22/Sekretnaya-laboratoriya-CHernobilya-raskrilasvoi.

Shcherbak, Iurii. Chernobyl: A Documentary Story. Translated by Ian Press. New York: St. Martin's Press, 1989.

Shestopalov, V., and V. Poyarkov. "Environmental Contamination." In The Chornobyl Accident: A Comprehensive Risk Assessment by Victor Poyarkov et al., edited by George J. Vargo, 97-179. Columbus \& Richland, OH: Battelle Press, 2000.

Siegelbaum, Lewis (interview with Kate Brown). ASEEES NewsNet 55.2 (2015): 7 .

Simon, Steven L., André Bouville, and Charles E. Land. "Fallout from Nuclear Weapons Tests and Cancer Risks.” American Scientist 94 (2006): 48-57.

Slaboshpytskyi, Myroslav. "Literatura na lito [Literature for the Summer]." Chytomo, July 11, 2016. Accessed August 14, 2018. http://www.chytomo.com/books-for-summer/5knig-yaki-radit-prochitati-rezhiser-miroslav-slaboshpick.

Smith, Jeffrey K. The Museum Effect: How Museums, Libraries, and Cultural Institutions Educate and Civilize Society. New York: Rowman \& Littlefield Publishers, 2014. 
Stepanets, Kirill, Denis Vishnevskii, and Sergei Paskevich. Chernobylskaia zona glazami stalkera [The Chornobyl Zone Through the Eyes of a Stalker]. Kyiv: Sky Horse Publishing House, 2017.

Strugatsky, Arkady, and Boris Strugatsky. Piknikna obochine [Roadside Picnic]. Moscow: Molodaia gvardiia, 1972.

Tarkovsky, Andrei. Stalker. Drama. 1979. (Release date in the U. S.: October 20, 1982.)

"The Chernobyl VR Project." The Farm 51, July 1, 2016. Accessed August 17, 2018. http:// www.thefarm51.com/projekt/chernobyl-vr-project/.

"The Nobel Prize in Literature 2015 (Svetlana Alexievich)." Nobelprize.org, 2015. Accessed August 13, 2018. https://www.nobelprize.org/nobel_prizes/literature/ laureates/2015/.

Tretiakov, Robert. Vybrana liryka [Selected Lyrics]. Kharkiv: Maidan, 1995.

Trokhym, Serhii. 1986: Chornobylski khroniky [1986: The Chornobyl Chronicles]. Brusturiv: Dyskursus, 2016.

Van Voren, Robert. Cold War in Psychiatry: Human Factors, Secret Actors. Amsterdam; New York: Rodopi, 2010.

Vargo, George J. "Editor's Foreword." In The Chornobyl Accident: A Comprehensive Risk Assessment by Victor Poyarkov et al., edited by George J. Vargo, xi. Columbus \& Richland, OH: Battelle Press, 2000.

"Vasilii Shamshin." Peoples.ru. Accessed August 15, 2018. http://www.peoples.ru/state/ minister/russia/vasiliy_shamshin/.

"V Kieve otkryvaetsia vystavka luchshykh molodykh khudozhnikov Ukrainy [Opening of an Exhibition of the Best Young Artists of Ukraine]." Fokus, December 1, 2010. Accessed August 17, 2018. https://focus.ua/society/15856o/.

Wanner, Catherine. Burden of Dreams: History and Identity in Post-Soviet Ukraine. University Park, PA: The Pennsylvania State University Press, 1998.

Watson, Jr., Raymond C. Radar Origins Worldwide: History of Its Evolution in 13 Nations through World War II. Bloomingtom, IN: Trafford Publishing, 2009.

Wenk, Jr., Edward. Making Waves: Engineering, Politics, and the Social Management of Technology. Urbana; Chicago: University of Illinois Press, 1995.

Yekelchyk, Serhy. The Conflict in Ukraine: What Everyone Needs to Know. New York: Oxford University Press, 2015.

Zabuzhko, Oksana. Muzei pokynutykh sekretiv [A Museum of Abandoned Secrets]. Kyiv: Spadshchyna, 2012.

Zabuzhko, Oksana. "Postskryptum: Monoloh perekladacha pro dzvin pokynutykh khramiv [Postscript: A Translator's Monologue about the Bells of Abandoned Cathedrals]." In Vybrane lystuvannia na tli doby: 1992-2002 by Oksana Zabuzhko and Yurii Shevelov, 473-80. Kyiv: Fakt, 2011.

Zanuda, Anastasiia. "Chornobyl-3o: spohady, zasvidcheni arkhivamy KDB [Chornobyl-3o: Memoirs Confirmed by the KGB Archives]." BBC Ukraina, April 25, 2016. Accessed August 17, 2018. http://www.bbc.com/ukrainian/ society/2016/o4/16o419_chornobyl_kgb_archives_memories_az. 
Zhukova, Ekatherina. “Trauma Management: Chernobyl in Belarus and Ukraine.” British Journal of Sociology 67.2 (2016): 195-215.

“2015 Sundance Film Festival Award Winners.” Sundance, 2015. Accessed May 15, 2017. https://www2.sundance.org/pdf/festival-info/2015AwardWinners.pdf.

\section{Archives}

DAKhO, the State Archive of Kharkiv Oblast (Derzhavnyi Arkhiv Kharkivskoi oblasti). Fond R 1962.

TsDAHOU, the Central State Archive of Civic Organizations in Ukraine (Tsentralnyi Derzhavnyi Arkhiv Hromadskykh Obiednan Ukrainy). Fond 1.

Vladimir Bukovsky Private Archive. Document 0202 (CT31/19). "About Psychiatric Care in the USSR" (February 18, 1972), p. 164.

\section{Interviews}

Iryna and Oleksandr, former liquidators and residents of Dniprorudnyi (Zaporizhzhia oblast, Ukraine). Interview conducted by the author (March 26, 2005).

\section{Correspondence}

Private communication with Fedir Oleksandrovych (FB; May 3, 2017).

Private communication with Kyrylo Stepanets (FB; March 28, 2018; May 28-31, 2018; August 13-16, 2018).

\section{唡}

Olga Bertelsen $(\mathrm{PhD})$ is a Jean Monnet Fellow at the European University Institute's Robert Schuman Centre for Advanced Studies (Florence, Italy) and a recipient of postdoctoral research and teaching fellowships at Harvard University (Ukrainian Research Institute), New York University (Jordan Center for the Advanced Study of Russia), Columbia University (twice - Harriman Institute and the School of International and Public Affairs), and the University of Toronto (Munk School of Global Affairs). She has published collections of archival documents on Ukrainian theatre director Les Kurbas and his "Berezil" theater (Kyiv: Smoloskyp, 2016), and on the persecution of Zionists in Ukraine in two volumes (On the Jewish Street, 2011). She is also the author of the monograph The House of Writers in Ukraine, the 193os: Conceived, Lived, Perceived (Pittsburgh, 2013) and the editor of Revolution and War in Contemporary Ukraine: The Challenge of Change (Ibidem-Verlag/Columbia University Press, 2017). 